Portland State University

PDXScholar

\title{
A study of art education in the elementary school curriculum as amplification of other academic subjects and as a promoter of creativity in the learning process
}

Jana Demartini-Svoboda

Portland State University

Follow this and additional works at: https://pdxscholar.library.pdx.edu/open_access_etds

Part of the Art and Design Commons, Art Education Commons, and the Curriculum and Instruction Commons

Let us know how access to this document benefits you.

\section{Recommended Citation}

Demartini-Svoboda, Jana, "A study of art education in the elementary school curriculum as amplification of other academic subjects and as a promoter of creativity in the learning process" (1982). Dissertations and Theses. Paper 3170.

https://doi.org/10.15760/etd.3159

This Thesis is brought to you for free and open access. It has been accepted for inclusion in Dissertations and Theses by an authorized administrator of PDXScholar. Please contact us if we can make this document more accessible: pdxscholar@pdx.edu. 
AN ABSTRACT OF THESIS OF Jana Demartini-Svoboda for the Master of Arts in Teaching in Art presented February 9, 1982.

Title: A Study of Art Education in the Elementary School Curriculum as Amplification of Other Academic Subjects and as a Promoter of Creativity in the Learning Process

APPROVED BY MEMBERS OF THE THESIS COMMITTEE:

Richard Muller, Chairman
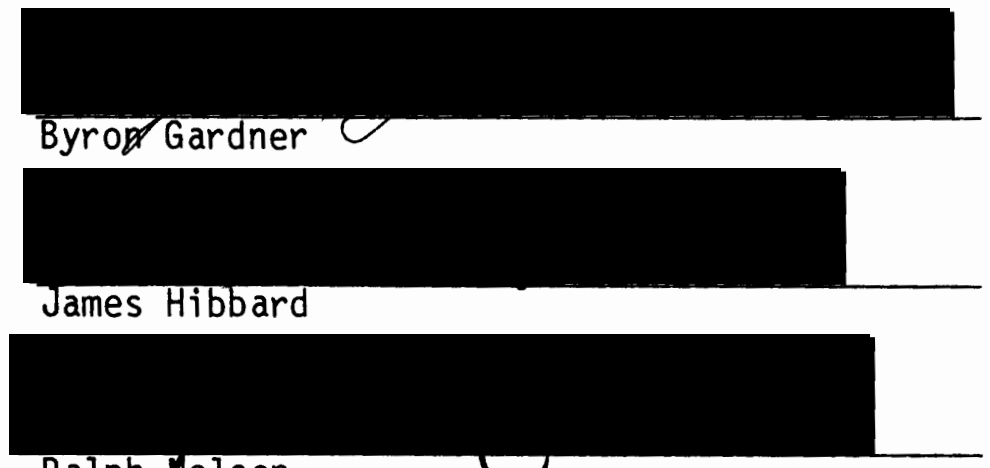

The goal of this thesis was to identify teaching interrelationships between art and other subjects in the elementary school curricula and thus indicate the usefulness of art education in the educational process.

For that purpose the writer conducted a series of projects based on a premise that art can be a unifying link between subjects in an integrated approach to teaching.

The thesis is divided into four chapters. The first two chapters summarize various views of and approaches to art education in the course 
of the last three decades. Detailed attention is given to some specific aspects of art which may play a positive role in an integrated educational process.

The core of the thesis is the third chapter in which three projects are described and analyzed. Each project attempts to identify some relationships of art with other academic disciplines and illustrate conditions under which teachers could make full use of such relationships. Each project is followed by a series of illustrations which is essential to the proper documentation of the methods used and the results attained. The outcome of this study indicates the significance of appropriate art projects with their emphasis on first-hand student experiences encouraging fuller emotional involvement for meaningful and successful learning.

The fourth chapter focuses on practical considerations for conducting more measurable and more persuasive research. It offers the conclusion that establishing and utilizing fresh connections between art education and other academic subjects may bring subject integrations beneficial to all children. 
A STUDY OF ART EDUCATION IN THE ELEMENTARY SCHOOL CURRICULUM AS AMPLIFICATION OF OTHER ACADEMIC SUBJECTS AND AS A PROMOTER OF CREATIVITY IN THE LEARNING PROCESS

by

JANA DEMARTINI-SVOBODA

\begin{abstract}
A thesis submitted in partial fulfillment of the requirements for the degree of
\end{abstract}

MASTER OF ARTS IN TEACHING

in

ART

Portl and State University

1982 
TO THE OFFICE OF GRADUATE STUDIES AND RESEARCH:

The members of the Committee approve the thesis of Jana DemartiniSvoboda, presented February 9, 1982

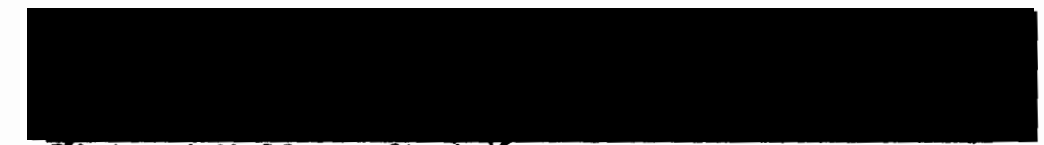

Richard Muller, Chairinan
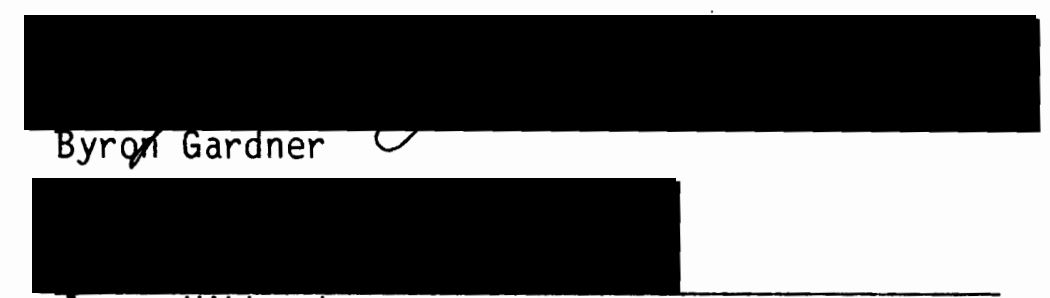

James Hibbard

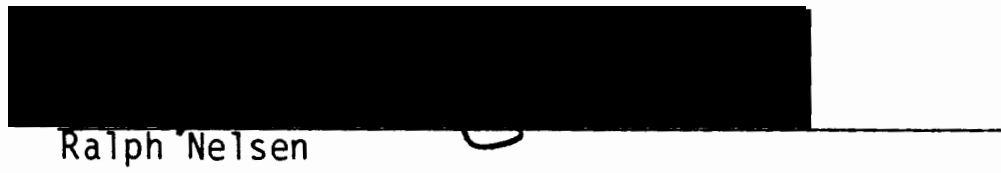

APPROVED:

Lenard Kimbrell, Head, Department of Art

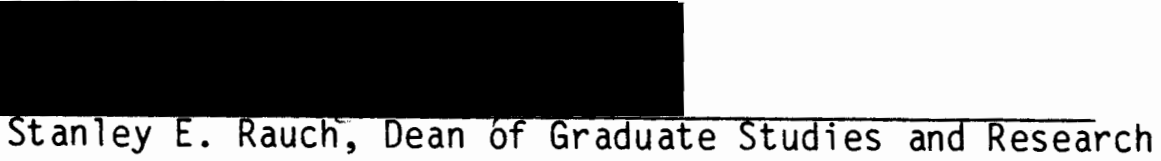


TABLE OF CONTENTS

PAGE

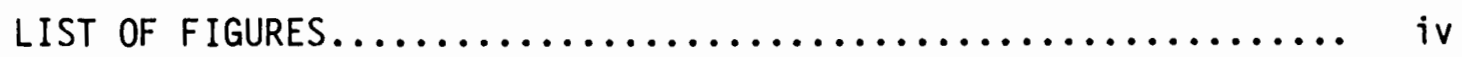

CHAPTER

I ART EDUCATION VIEWED AS AN IMPORTANT PART OF THE WHOLE EDUCATIONAL PROCESS: GENERAL VIEW............ 1

II SOME SPECIFIC EDUCATIONAL CONTRIBUTIONS CLAIMED FOR ART EDUCATION............................. 6

III EXPLORATION OF SOME POTENTIALS IN LINKAGE OF ART EDUCATION WITH OTHER SUBJECTS IN THE ELEMENTARY

SCHOOL CURRICULUM......................... 15

Project I - Art and Science................ 16

Project II - Art and Talented and Gifted........ 35

Project III - Art and Language Arts.......... 46

IV CONCLUSIONS.............................. 56

SOURCES CONSULTED............................. 59 


\section{LIST OF FIGURES}

FIGURES

PAGE

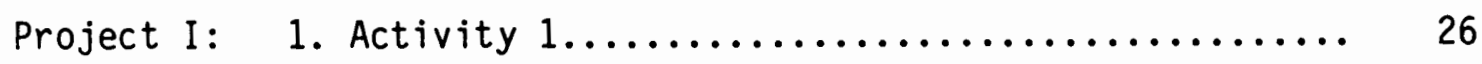

2. Activity 1 (continued) $\ldots \ldots \ldots \ldots \ldots \ldots \ldots .26$

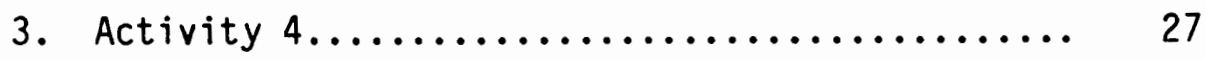

4. Activity 4 (continued) $\ldots \ldots \ldots \ldots \ldots \ldots \ldots \ldots, 28$

5. Activity 4 (continued) ............... 29

6. Activity $5 \ldots \ldots \ldots \ldots \ldots \ldots \ldots \ldots \ldots . . . \ldots \ldots$

7. Activity 5 (continued) $\ldots \ldots \ldots \ldots \ldots \ldots \ldots .30$

8. Activity 5 (continued) $\ldots \ldots \ldots \ldots \ldots \ldots \ldots .30$

9. Activity $7 \ldots \ldots \ldots \ldots \ldots \ldots \ldots \ldots \ldots \ldots . . . \ldots \ldots$

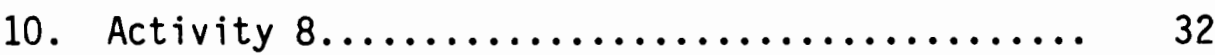

11. Activity 8 (continued)............... 33

12. Activity 8 (continued) $\ldots \ldots \ldots \ldots \ldots \ldots \ldots \ldots, 34$

Project II: 13. Hypothes is by D., 3rd grade.............. 41

14. Result of the actual observation by the same
student as in Figure $13 \ldots \ldots \ldots \ldots \ldots \ldots \ldots \ldots . . .61$

15. Hypothes is by J., 3rd Grade............. 42

16. Result of the actual observation by the same student as in Figure $15 \ldots \ldots \ldots \ldots \ldots \ldots \ldots . . . \ldots . .42$

17. Hypothes is by L., 4th Grade............. 43

18. Result of the actual observation by the same student as in Figure $17 \ldots \ldots \ldots \ldots \ldots \ldots \ldots$ 
FIGURE

PAGE

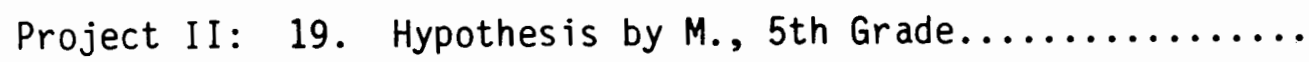

20. Result of the actual observation by the same student as in Figure $19 . \ldots \ldots \ldots \ldots . . . .$.

21. Hypothesis by J., 5 th grade............ 45

22. Result of the actual observation by the same student as in Figure $21 . . . \ldots \ldots \ldots . . . .$.

Project III: 23. Stranger in our class................ 52

24. Student drawing.................... 52

25. Student drawing.................... 53

26. Student drawing.................... 53

27. Student drawing..................... 53

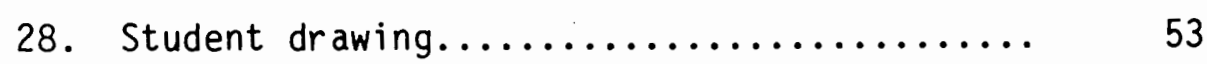

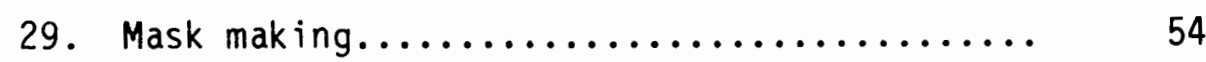

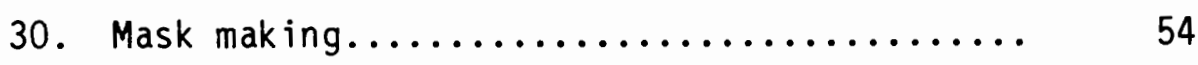

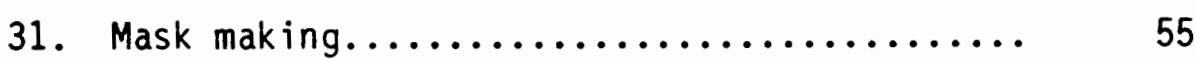

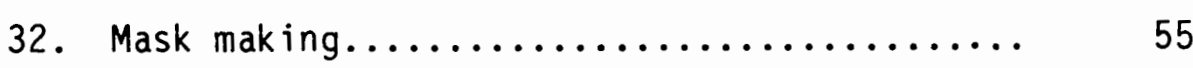


CHAPTER I

ART EDUCATION VIEWED AS AN IMPORTANT PART OF THE WHOLE EDUCATIONAL PROCESS: GENERAL VIEW

The growing interest in all kinds of art forms and programs indicates that the American public now recognizes the importance of art in individual lives. However, the potential value of art in the education of all students is still largely misunderstood. This is so even though there has been enough data gathered in the past three decades of research to support the theory that art education can be considered central to one's education.

After World War II greater attention was paid to the individual student and the actual influence of the educational process. Educators became aware of the significance of creativity for healthy mental growth and for balanced learning as researchers uncovered new findings in this area. "The real value of creativity in education is that it helps a student to be definite in his attitudes and enlarge his general capacity for perceiving, thinking, and feeling."1

Through numerous studies it was possible to define some of the qualities of "creative ability". Among such qualities belong curiosity, capacity for divergent thinking, willingness to question, rejection of superficial or conventional explanations, sensitivity to problems,

1The Open Eye in Learning: The Role of Art in General Education, ed. Richard Bassett (Cambridge, Mass., The MIT Press, 1969), p. 22. 
self-confidence, tolerance of ambiguity, willingness to avoid absolutes, flexibility of mental habits, fluency of ideas and expression, and ability to adapt to a new situation. 2 But most importantly, based on a research in the University of Buffalo, it was concluded that creativity can be deliberately developed. 3

The findings from this research are in line with Guilford's conclusion that although heredity may place limitations on the skills involved in creativity, these skills can be extended within those limitations through education. 4

From this discovery it did not take long to deduce that art education might be used as an essential tool for developing creativity. "The available data so far suggest confirmation of the common assumption that art education can promote creativeness beyond the arts." 5

As interested teachers began to test these assumptions by adapting the results of new discoveries to their teaching methods, accounts of excellent results were published and there developed many new theories on the importance of art in education.

With the growth of affluence of the American society in the sixties and the seventies, accompanied by changes in the perceptions of social values, especially with the emphasis on self-fulfillment, the

2William H. Burton, The Step Beyond: Creativity (Washington, D.C., National Education Association of the United States, 1964), p. 20.

3Sidney J. Parnes, "Can Creativity be Increased?", Creativity and Art Education, ed. W. Lambert Brittain (Washington, D.C., The Nationa) Art Education Association, 1959), pp. 45 \& 51.

4 Ibid., p. 49.

5 Research in Art Education, ed. Jerome Hausman (Washington, D.C., The National Art Education Association, 1959), p. 43. 
role of art in teaching creativity grew even more important. As the attention to processes and outcomes of the art in education became more focused, educators discovered other aspects of art playing an important role in the healthy development of the individual. The strong communicative attributes of the arts became stressed. "Communication through the various artistic forms, visual, musical, or literary, is probably the closest communication that ever happens between mind and mind." 6

This recognition of the communicative aspects of art was linked to the task of teaching a new generation about its cultural heritage. "Art is a means of communication from one generation to another, it establishes continuity in the culture."7

As self-expression became the top priority of the seventies, the arts were acknowledged to be most instrumental.

Music, dance, drama, and art are man's natural and essential means for self-expression. They assist in leading man to an understanding of himself and the world in which he lives.

Since the arts are integral to man, they must be central in the educational experiences of all children. 8

As interest in the quality of life grew, some researchers expressed the need to develop opportunities for students to explore their own creative identities and discover unexpected potentials. They realized that through the creative experiences in art one sharpens one's senses and learns to perceive the world more vividly and accurately, thus be-

6The Open Eye in Learning..., p. 26.

${ }^{7}$ Art Education in the Elementary School, ed. Mary M. Packwood (Washington, D.C., National Art Education Association, 1967), p. 8.

8An Oregon Report: Arts and the Handicapped, ed. Steve Brannan and Carol Leitschuh (Portland, Portland State University, 1967), p. 7. 
coming more sensitive to one's environment. All of this was considered important to developing skills necessary for leading a meaningful life.

Hope Pressman, then the chairperson of the Oregon Arts Commission, expressed these convictions of art educators at the Conference on Art and the Handicapped held at PSU in 1976:

Art facilitates the 'inner journey' of the human potential the goal of developing and accepting oneself, and of harmonizing and integrating one's motives. ${ }^{9}$

More recent development in the research of the human brain and its functions have raised more questions about traditional educational methods which stress the intellect to the detriment of the intuitive and emotional attributes.

The left brain hemisphere is still considered by many to be the major one. Scientists have determined that control of speech functions is located there. Since language and thinking have historically been considered inseparable, it has been assumed that the left brain was responsible for all our cognitive thinking. Therefore educational programs in our schools have stressed use of the left mode. However, new research in neuropsychology has uncovered that the right brain hemisphere, considered the less developed one, dependent on the left half, is possibly more of an equal partner to it in the sense that it excels in specific functions. It is the place where our intuitive, spatial and relational controls are located. There is little doubt that both hemispheres collaborate in processing of information, because "both hemispheres use high-level cognitive modes which, though different, involve

$$
9 \text { Ibid., p. } 13 .
$$


thinking, reasoning, and complex mental functioning."10 The most recent studies also point to the balancing effect of both hemispheres on ones emotions.

The left hemisphere seeks out a succession of isolated, specific details. Withdrawal is into a space, featureless, but of defined dimensionality. Just as accurate cognition depends on meshing the functions of both hemispheres, so does a balanced emotional reaction to a situation. One hemisphere evaluates the pros, the other the cons. Integrating these separate contributions produces balanced, healthy states of both thinking and feeling. 11

These findings show how important it is to address both hemispheres in the learning process. And the scientific evidence has only confirmed the foresight of such educational authorities as Sir Herbert Read and Viktor Lowenfeld, both of whom advocated such educational programs, in which the focus on intelligence and creativity would be in balance, because both are "essential to human growth".12

10Betty Edwards, Drawing on the Right Side of the Brain (Los Angeles, J.P. Tarcher, Inc., 1979), p. 30 .

$11_{\text {Marcel Kinsbourne, "Sad Hemisphere, Happy Hemisphere", Psychology }}$ Today (May, 1981), 92.

12 victor Lowenfeld, "Creative Intelligence", Creativity and Art Education. p. 8. 
CHAPTER II

SOME SPECIFIC EDUCATIONAL CONTRIBUTIONS CLAIMED FOR ART EDUCATION

Our educational system is an integral part of our society and as such is influenced by economic and political circumstances. It is expected to express its values.

While the sixties were times of greater economic prosperity and ideological tolerance, the eighties seem to be developing differentiy.

In these times of economic difficulties and tight budgets, schools will try to economize by cutting off programs which they consider nonessential. Unfortunately for art education and despite all existing studies identifying it to be a valid tool in the educational process, it has been historically one of the first areas of the curriculum to be cut. Art education is still considered peripheral and has seldom been given a central role in the educational process.

Under these circumstances nothing will influence attitudes as much as good, practical examples on the local level. Thus, the initiative lies inevitably with teachers who believe in these qualities and in their own ability to direct the development of it in their own students.

Viewed through these problems, the single most distinctive aspect and unique characteristic of art in education seems to be its integrative quality. 
Over the ages art has permeated all human activity. It has often been the most significant tool man has discovered on his way to become human. Through art and artifacts, anthropologists learn about ancient man, historians can tangibly interpret man's endeavors, psychologists are aided in analysis in human mental processes. Mathematicians and astronomers - among the most dependent upon factual data - have learned about their ancient ancestors through art. The first written languages were based on concrete communicative symbols. Innovations toward abstraction developed long after personally intricate expressive means of art were established.

But we can say that art has always assisted and advanced learning in ways which have not frequently been recognized, even among scholars. Yet art has traditionally been associated with a man's awareness of himself as human. Because it constantly addresses the need of human beings it maintains its role as a positive force in the society. Those who cannot bring into the play their own perceptions, experiences, and aesthetic sensitivities, do not make compatible participants in the experience of either art or education.

Unfortunately, as our society grows more complex, these qualities are being more and more neglected and the gap between our first-hand experiences and our more general knowledge grows ever wider. Children are presented with concepts much removed from the reality upon which they were originally based and are not encouraged to gain further knowledge through their own experiences and to learn by their own cognitive associations. Perhaps then we should not be shocked to discover that some researchers find that our college students are not able to perceive 
relationships in the world despite the proof that they have the "necessary knowledge".

Our present educational system with its predominant emphasis on verbal mode and on divisions of the mental processes does not prepare the students sufficiently for the challenges of life.

John Goodland from UCLA comments on the position various subjects occupy in the school program:

A study conducted several years ago in Portland, Oregon, causes one to sit up sharply. After studying time distributed among subjects in the primary grades, the researcher concluded that mathematics, reading and language arts consume so much classroom time that only a few minutes a day are left for everything else - social studies, science, and arts. Several colleagues and I, studying classrooms in 67 elementary schools, concluded that language arts dominate the curriculum. This does not mean that "language arts" as a subject appears to take up most of the time. But when one examines the way instruction in all subjects is carried out, one is forced to conclude that language arts dominate.13

And the tendency to go "back to basics", as seemingly presentiy understood, will not make the situation any better.

The basic skills stress only the form, rather than the content or meanings inherent in the language, and they include verbal and mathematical forms of symbolic codes, and none of the others. The fallacy lies in the presumption that the verbal and mathematical codes include all meanings necessary for adult functioning. 14

Perhaps we need to return to basics but by that should be meant the re-evaluation of the purpose of our education and the needs of the students in the educational process. On that basis we have to determine

13 Arts Education and Back to Basics, ed. Stephen H. Dobbs (Virginia, National Art Education Association, 1979), p. 23.

14 Ibid., p. 43. 
truly usefur teaching approaches and the clarification of the essential qualities of the learning process.

From the recent discoveries into brain function, mentioned earlier, we know that we depend on the use of both hemispheres for well balanced mental processes. This places new responsibilities on the school programs and teachers in conducting the educational process.

From tests and related studies we now know, that many things $c$ an be learned creatively by questioning, experimenting, exploring and testing ideas more effectively than by authority. Children can be taught in such a way that their creative thinking abilities can be used to acquire the traditional education skills and that these abilities are quite different from those measured by our traditional educational intelligence tests. 15

When we analyze the skills learned through art education we find that they are compatible with those needed for successfur learning of any subject.

The basic skills that are necessary for experiencing art are those skills, that are necessary for the processing of knowledge $1 \overline{6}$ perceiving, interpreting, understanding, and expressing. 16

It should also be taken into account that for fuller functioning in the society we need to develop the ability to see the relationships between separate pieces of information and our stored knowledge. We have to look for methods which would stimulate an integrative, not compartmentalized way of thinking.

15Paul Henrickson and E. Paul Torrance "Some Implications for Art Education from the Minnesota Studies of Creative Thinking," Creativity and Art Education, p. 19.

${ }^{16}$ Arts Education and Back to Basics, p. 34 . 
Because the mental processes cross academic lines, the relationship between courses should be close, and stimulating experience in one area ought to be reflected in other areas.17

Art, with its strong stimulative and integrative qualities, should be in the center of such approach, because "it is the most natural mode for children -- and as such, its material is the whole of experience. It is the only mode that can fully integrate perception and feeling." 18 More attention should be paid to the process of the art experiences than is commonly the case. Most teachers are still hung up on anticipated product, not realizing that although both elements in the art experience are important, it is through the process that children learn. Because "creativity cannot be learned at older age levels,"19 it is reasonable to expect that the implementation of such experiential programs must start from the lowest grades in the educational system. "Children who are rarely affected by perceptual experiences show little ability to observe and little awareness of differences in objects." 20

Children must be allowed to perceive through their own experiences and to develop their personal expressive means without unnecessary and insensitive interferences from others.

\section{${ }^{17}$ The Open Eye in Learning:..., p. 33.}

18Herbert Read, Education Through Art, 2nd ed. (New York, Pantheon Books, A Division of Random House, n.d.), p. 60.

19 Viktor Lowenfeld and $W$. Lambert Brittain, Creative and Mental Growth, 5th ed. (London, The Macmillan Co., 1970), p. 46.

20 Ibid., p. 29. 
Unfortunately, the moment the child reaches the early expressive stage, it is almost inevitable, that someone - teacher, parent, or other child - gives him a few static patterns that end art as a genuine means of expression.21

This may stem from an impatience with the child's expressive vocabulary due to a lack of information and thus a lack of understanding of the child's expressive development. According to Viktor Lowenfeld, the child's artistic abilities develop through several successive stages:

1) Scribbling Stage represents the child's earliest drawing attempts and lasts until about the age of four.

2) Preschematic Stage covers the age from four to about seven and shows first representational attempts on the part of the child.

3) Schematic Stage. In this stage, lasting until about nine years of age, the child is developing a "definite form concept" and is most vulnerable to improper adult influence.

4) Stage of Dawning Realism, embracing the age of nine to twelve, shows the child's growing interest in his surroundings and depiction of details. He is at the height of his creative powers.

5) Pseudo-naturalistic Stage, beginning around the age of eleven or twelve, is the last link in the chain of the child's artistic development and quite short one. With the development of reasoning comes increasing awareness of the child's environment and his place in it, which leads to self-criticism. Unfortunately, for many it also means an end to further artistic development. 22 But, perhaps, based on the

21 Mildred M. Landis, Meaningful Art Education (I11inois, Chas. A. Bennet Co., Inc. Publishers, 1951), p. 104.

22Lowenfeld and Brittain, pp. 36-39. 
convincing experiments of Betty Edwards who appears to have achieved excellent results with teaching drawing through use of the right hemisphere of the brain, 23 the fault lies with the inadequate training of the mind. The main concern here is not with educating artists but with nourishing observant, creative personalities whose mental faculties develop in balance. In order to accomplish such results, we must use alternative approaches in teaching.

For those children in the preschematic and schematic stages the most appropriate influence the teacher can exercise is to provide plenty of opportunities to perceive through first-hand experiences and to learn to manipulate various materials through which their expressive abilities will become evident. On this basis the teacher can successfully build and expand lexical and grammatical modes. 24

However, in the last two developmental stages it is important that the students be directed in the development of their observative powers and in training of the eye-hand coordination, and instructed in what they come to understand as aesthetic qualities. Then individual cognitive, creative, and aesthetic skills will be encouraged to develop in harmony.

Some schools have tried such programs with the intent to prove that the art experiences can influence positively the learning process in other academic subjects. And indeed there have been many encouraging reports from teachers as well as from administrators. One of them, the

23Edwards, pp. 10-13.

${ }^{24}$ Arts Education and Back to Basics, p. 91. 
principal of Public School 3 in New York, relates in his report on his school Arts in Education Program:

It is clear that for some children an approach through arts unlocks barriers which have almost inhibited their capacity to profit from school experience. For a large number of children expressive work in the arts can add so much zest to their experiences and so much confidence, independence, and capacity to perceive in an endeavor that their overall school experience is greatly advanced. In the most developed classrooms in the school the arts approach has been carried throughout the curriculum so that aesthetic awareness and the urge for personal expression pervades everything that the children do. In these classrooms the standards of work in all areas have been significantly higher than in other classrooms where a more traditiona) approach was used. 25

Many other educators and researchers have voiced their opinion to the same effect; however because the researchers have not found a way to measure these relationships exactly, Kathryn Bloom warns that "it is not possible to attribute gains in general learning directly to the arts on one-to-one, cause and effect basis." 26

This should not deter us from continuing to look for such relationships between art and other subjects especially since we already know that there are other important aspects of the learning process, which we do not measure; yet we continue in those procedures just because they are customary - as for instance the child's readiness to enter school or faster and slower development of children's mental faculties within one grade level.

$$
\begin{aligned}
& 25 \text { Ibid., p. } 137 . \\
& 26 \text { Ibid., p. } 140 .
\end{aligned}
$$


The recent Art Advocacy Conference held in Salem 27 called for more studies in this field because enlightened educators believe that there is a wealth of untapped possibilities in the integrative approach to learning and that the art experiences, if applied wisely and in a meaningful way, can be the unifying force in this process.

${ }^{27}$ Art Advocacy Conference, Salem (spons. by Ore. Alliance for Arts Educ., Arts Coalition N.W. - Seattle, Oregon Dept. of Educ., Canby Elem. School Distr.), 3rd annual, March 27, 1981. (unpublished notes). 


\section{CHAPTER III}

EXPLORATION OF SOME POTENTIALS IN LINKAGE OF ART EDUCATION WITH OTHER SUBJECTS IN THE ELEMENTARY SCHOOL CURRICULUM

In this study I have focused attention on the integrative approach in education and how art education can contribute to it. My goal was to identify some relationships of art with other academic disciplines, to look for conditions under which teachers could make full use of such relationships, and to define the possible gains such connections could bring to their own teaching.

For specific projects I was seeking situations in which the art experiences would provide a sound environment for creative thinking and would stimulate children's inquiring behavior. While I was hoping to reach some measurable results, I had to take into account that such results would very much depend upon the instructional context and individual understanding and cooperation of the teacher with whom I would work.

I designed projects which concentrated mainly upon art and science because of the strong indicators that creativeness in both disciplines has many common attributes 28 , and that art, being much more involved with feelings and personal expressions can be the balancing element in the objective, analytical approach of science.

28Research in Art Education, p. 43. 
I was intrigued with the argument that in art "knowledge can be applied as soon as it is learned." 29 I was also interested in the premise, that art can provide "the bridge between the raw experience on one hand and such abstract codes as mathematics and literature on the other." 30

\section{PROJECT I}

\section{ART AND SCIENCE}

In the first project I drew upon Read's requirement that play be an important part of the learning process of children. This is not Read's original idea, he only expanded Dr. Margaret Lowenfeld's theory. He substituted the word art for play, meaning that play is a form of art.31 He also cites Caldwell Cook's (English teacher from the turn of the century) eloquent description of this method of learning through play (art):

Play, as I mean it, goes deeper than study; it passes beyond reasoning, and, lighting up the chambers of imagination, quickens the body of thought, and proves all things in action. The study of books, however thorough, may yet remain but superficial, in the sense that there may be no feeling of reality behind it. 32

The idea of learning through play goes back to 17 th century when Comenius in his writings first demanded that learning should be done in

${ }^{29}$ The Open Eye in Learning..., p. 53.

30 Arts Education and Back to Basics, p. 88.

$31_{\text {Read, pp. 109-110. }}$

32 Ib id. , p. 227. 
a form of play and with all senses involved. 33

To my understanding, play is a creative activity with manipulation of objects and ideas as its focal point. With children, because of the immaturity of their abstract thinking, this manipulation should involve physical activity in which all senses take part.

My initial study was done with a fourth grade class. After planning with the teacher, we decided to tackle a unit on scale drawings from which teachers usually shy away. The reason for the aversion, I assume, is that with the use of traditional teaching methods the concept is difficult for the children to grasp. It is based on comparative thinking which most children cannot be expected to use successfully for lack of previous related experiences.

The school in which I was doing this study is a modern facility, well equipped for new teaching methods. Science teachers have available and are encouraged to use a whole science course designed by the American Association for the Advancement of Science, called Science....A Process Approach II. 34 It contains a series of modules which should be taught in groups of sequences, according to their inner relationships.

In the module on scale drawings from this series, the children are required to do some drawings of objects from their environment, but the major activity revolves around comparison of pictures drawn to a given scale. On the whole, the approach seemed too dry and academic. Though

33Jan Amos Comenius, Scholarum Reformator Pansophicus, trans. to Czech by Jan Patočka, (Praha, Státní Pedagogícké nakladatelství, 1956). 34(Lexington, Mass., Ginn and Comp., 1974) module 47. 
the authors tried in some cases to satisfy the children's need for novelty by, choosing for comparison animals such as a dinosaur and a flying squirrel, they did not consider the fact that children may not naturally visualize the true life-size of such animals based on numbers alone. My premise was that the basic need of the children, if they were to comprehend the concept of the scale drawings, was to live the experience of the true life-size versus the scaled representation of the object.

My second requirement was to have as much physical involvement in the learning process as possible, which meant actual drawings being produced by the children.

We decided to aiter the prescribed route and attempt to teach the whole unit through art experience and concentrate on enlarging by grid. Our objectives were to teach the children to understand the concept of changing scales on which the more detailed objectives of the original module could be built more easily. The original objectives were:

1. Distinguish between representation of objects that are lifesized and those that are not.

2. Describe the relationship between the actual size of an object and its representation when the scale is given.

3. Demonstrate a procedure for drawing an object to a given scale.

Initially we planned the unit in five activities with eyes open for possible integrative situations.

Activity 1 -- To establish a continuity between science units we started with discussion about a mural in the class, done by the children 
in a previous unit on sea animals. The animals there were depicted in various sizes without correlation to their true life-sizes. The children were aware of some of the discrepancies and also knew that different distances influence our perception of size.

I selected the whale to become our point of departure for the unit on scale drawings. Because the children did also a research on the animal they chose to paint, the boy who depicted the whale gave the class a report about it. We learned that the whale can grow to a length of approximately 100 feet.

At this point, because the children have learned to use meters in mathematics and because it seemed a good opportunity to correlate the two, we converted the 100 feet into 33 meters.

Each child received a meter stick and the whole class went out to the black-top school yard, measured the $33 \mathrm{~m}$ collectively and drew a whale that size with chalk (Figure 1 and 2). After that we walked inside and on the perimeter of the whale to experience the hugeness even more.

The children (and the teachers too, for that matter) were surprised by the actual size of the animal and immediately started to pretend that the fish had swallowed them and that they were in its belly. It was a clear signal that their emotional involvement had been awakened by the sensual experience.

Activity 2 -- After a break we continued. The children measured the length of the small drawing of the whale on their mural and calculated how many times it would fit into the length of the life-size whale. We 
established the ratio, which was $1 / 58$, and talked about the word scale and what it means.

Then we talked about other examples of animals depicted in sizes smaller than their actual life-size and the reason for it. For the examples I brought art reproductions from different historical times and different places, which gave children the opportunity to glimpse art history as well. Besides the theme of depicted sizes in comparison to the true life-sizes, we paid attention to the rendering of animals by different artists in different times and located on a world map the countries from which they originated. Thus we also touched upon geography. The map was another excellent example of scale drawing which we utilized.

Activity 3 -- The next time we gave each child a copy of an animal drawing (the art line drawings from our previous discussion), a $1 \mathrm{~cm}$ graph acetate, and a marker. Their task was to copy the line drawing onto the graph acetate and observe what happens in each square as opposed to the whole drawing; how many squares are to the length and how many to the height; what it means when each square is $1 \mathrm{~cm}$ and to check for correctness by measuring the length and the height with a cm ruler.

Here we met an obstacle since the children were not easily able to focus their attention on a single square until they covered the rest of the drawing with strips of paper so that only the desired square was left visible. Then they saw the seeming incongruities of the design within the square which seemed unrel ated to the whole. Their comments about this revealed their keen observation and natural associative abilities: "It looks like a river in the landscape." or "This triangle 
here looks like a mountain." Thus, we established the concept of the part-of-a-whole, which was to become a familiar term used not only by the teacher, but by the children too.

However, at this point we also realized that the next activity might be too difficult for them to handle if we did not prepare them with more exercises revolving around the single square design. So we inserted another activity.

Activity 4 -- Each child received three different sizes of graph paper. Under the direction of the teacher, who worked with the class on the overhead projector using graph acetate, the children placed a diagonal in one square of the smallest size graph paper, then transferred the same pattern onto the square of the larger graph and eventually onto the square of the largest graph paper. They continued in this fashion with other design elements, until at the end of the session they felt free to use their own elements and even combination of more squares into a design unit and transferred them successfully onto the other sizes of the graph paper (Figures $3,4,5$ ). Then we returned to the originally planned activity, which now became activity 5 .

Activity 5 -- The students received copies of a line drawing, Calder's wire sculpture of a cow. The drawing was on a graph paper so the design was divided into separate squares. Each child was assigned one square (the rest of them were hidden by paper strips as previously) which he/ she was supposed to enlarge ten times on another graph paper. The children first had to count ten squares each way on that graph paper and mark their field for the enlargement (Figure 6 ). Then we analyzed the 
process of the enlargement of one square with the teacher demonstrating on the overhead projector. We compared the centimeters on the large $10 \mathrm{~cm}$ square to millimeters on the original $1 \mathrm{~cm}$ square. However, there was a visual discrepancy for the children which they had a hard time to overcome. The large $10 \mathrm{~cm}$ square was divided by the grid of the graph paper into the $1 \mathrm{~cm}$ squares, while the original square to be enlarged was just one single square.

After the children completed the task with various levels of success we assembled the each child's enlarged squares back to form the cow, this time 10 times larger (Figure 7). Then with the original small drawings in hand we corrected collectively the individual squares so that the lines would meet properly (Figure 8 ).

This was a demanding lesson and only about $30 \%$ of the class was able to complete it with full success. Part of the problem was, as stated above, the perceptual conflict between the visual character of the two squares. Also, the $1 \mathrm{~cm}$ square seemed so small against the $10 \mathrm{~cm}$ square that most of the children, not having enough previous encouragement in developing their skills in spatial thinking, could not handle the massive scale change. I also suspect that the drawing, though simple, could have been even more simplified. Better yet, had we combined it perhaps with biology, we could have had the children produce a drawing as a study of a butterfly or some other simple insect and to use it for the enlargement. This less abstract imagery might have seemed more relevant to them. It was also obvious that they needed more of these activities to fully comprehend the relationship of the growth of the design with the growth of the grid. 
Activity 6 -- In the next session we showed the film Power of 10 by Charles Eames, which illustrated beautifully the same concept and helped to enlarge upon their grid designs.

Then the teacher added more activities in which she returned to the simple square exercises, eliminating any talk about $\mathrm{cm}$ and $\mathrm{mm}$, just playing with small and large grids of the graph paper. Activities 7 and 8 -- Both of these lessons were intended to apply knowledge of the concept acquired in the previous sessions and to further develop understanding of it as well as technical skills of scale drawing.

In both sessions the children first created their own designs on a smaller grid and then transferred it to the larger grid. Because there was a square for square ratio, we found they could handle more complex designs (Figure 9).

By this time it was also getting much easier for them to see the spatial relationships and to maintain original shapes. Their imaginative designs indicated their enthusiasm in pursuing the goal as they became aware that they could use and manipulate their own ideas (Figure 10). Their creativity was unleashed, as we can see in the example of Rochelle and David. Rochelle made a mistake in the transfer of the design and was unhappy about it until she suddenly found a solution. She cut off the corner where the error occurred, thus incorporating a new idea into her design (Figure 11). David, who is a visually talented boy, saw the potential of this newly acquired skill for his own purpose and did not hesitate to use it. In fact he has used it ever since, enlarging his drawings of cars and rockets with great zest (Figure 12). 
Unfortunately, I think that the teacher got carried away with the idea of play. With the overemphasis on the geometric designs the children did not get enough feedback on the relationships between objects and their scaled drawings. Also, by eliminating references to the initial purpose of the unit, their theoretical knowledge was not reinforced. Had the teacher realized that discrepancy she could have corrected it and may have accomplished more fully the aims of the original science unit.

These observations were confirmed by the results of a two-part competency test: a practical demonstration that required the children to draw their own hand on a graph paper and transfer it to $1 / 2$ scale on another paper with half the size of the initial graph. In the theoretical part they were asked two questions: 1 . What does scale mean? 2. What does $1 / 2$ scale mean? In a way this test was more difficult than the one from the original science unit. The children were required not only to compare and distinguish between the life-size object and its representation in a given scale, but had to actually produce the representation in the given scale by themselves. Still, most of the children were able to respond positively to the first part, but they could not answer correctly the theoretical questions. I feel that much of their difficulty with the theoretical part was caused by the general wording of the questions. What seems clear is that the test required a verbal definition which the children could not provide due to the previously mentioned omissions in the later part of our project. However the children demonstrated skills in the visual concepts which was our original goal. Had we not lost track of the integrating idea in the 
final stages of the unit, we could have achieved the full competency as required in the original science unit with results supporting the premise that through a balanced combination of art and science the children could gain measurably deeper knowledge of both subjects than when the two disciplines are taught separately. It would be interesting to repeat the unit on scale drawings as prescribed by the science...A Process Approach II next year with the same group and learn what impact this type of project can have on the future speed and understanding. 


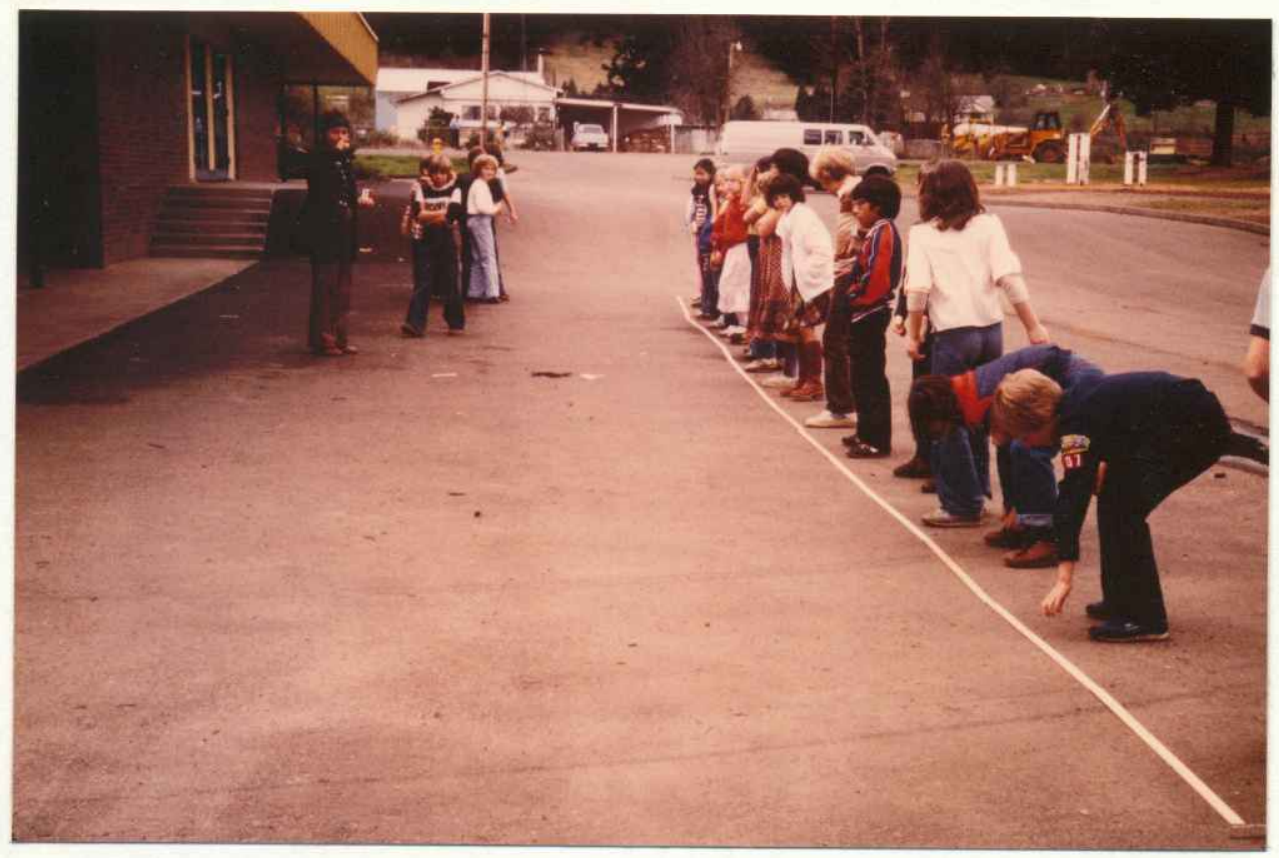

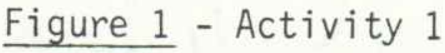

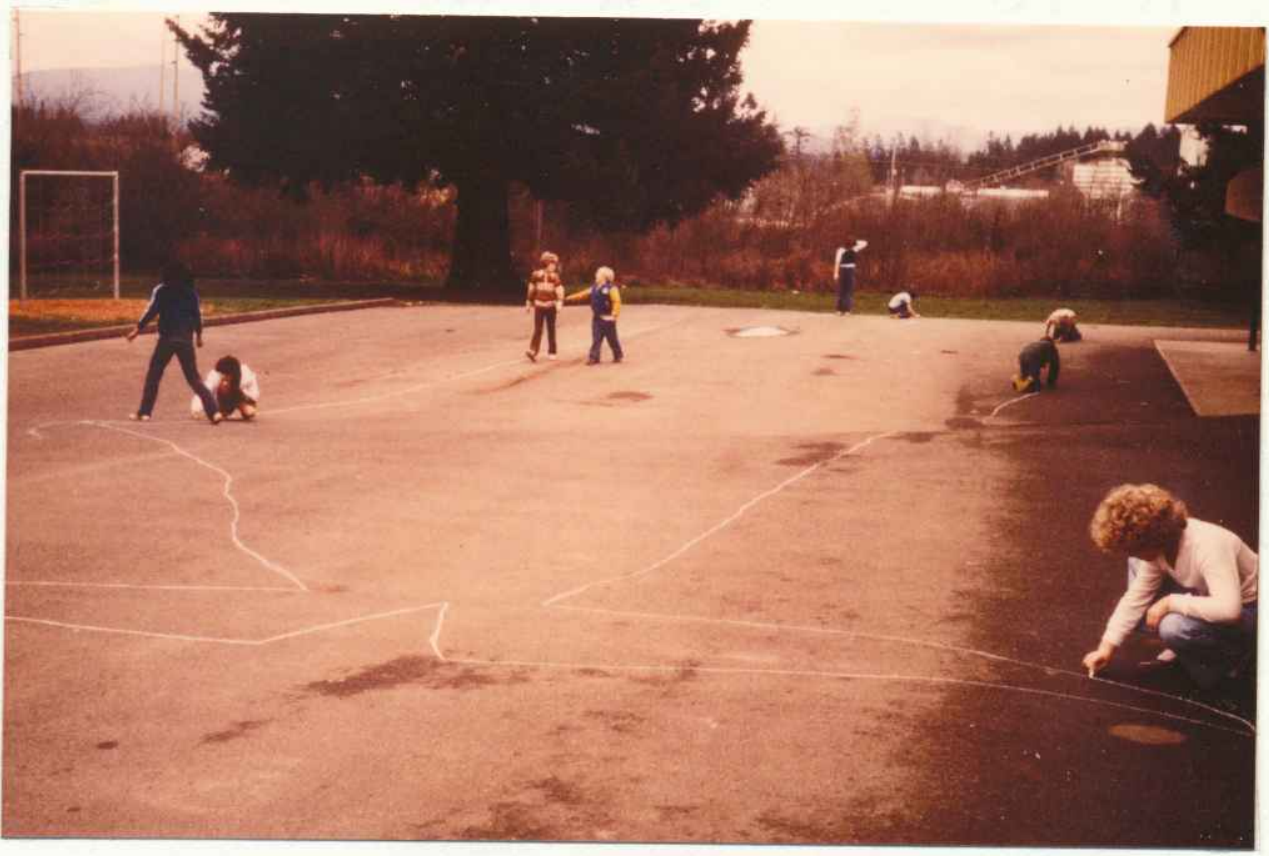

Figure 2 - Activity 1 



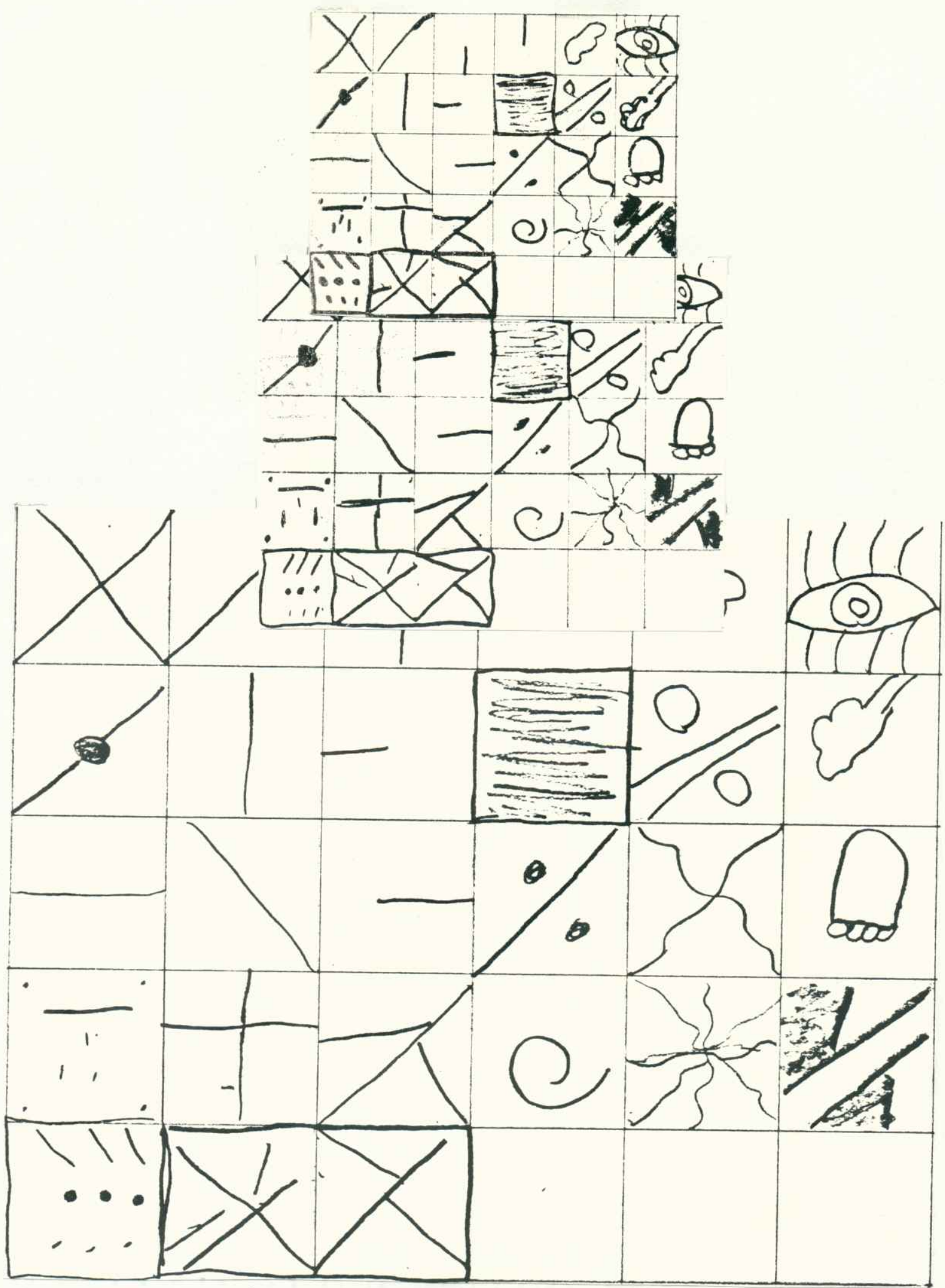

Figure 4 - Activity 4 (continued) 


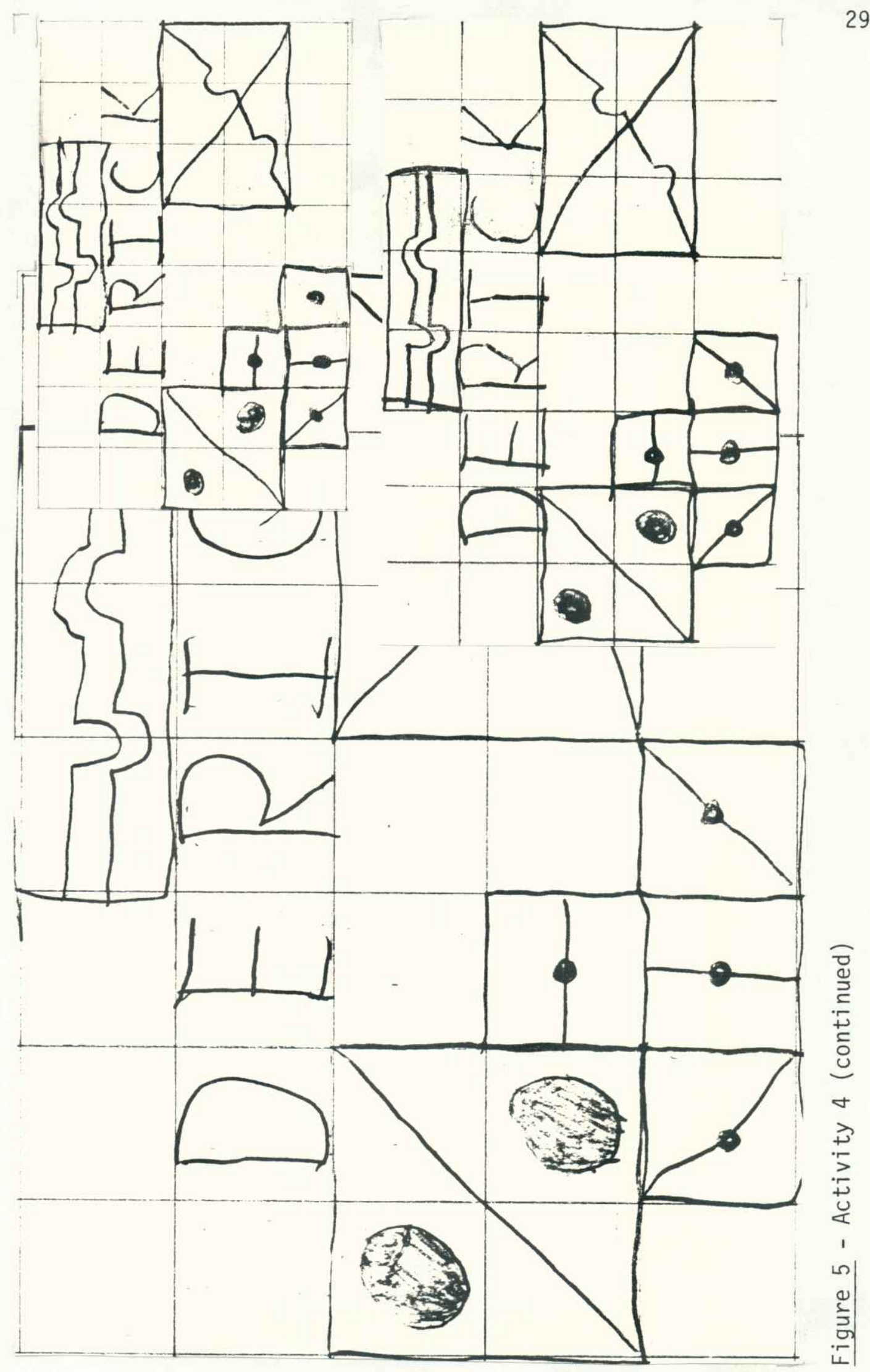




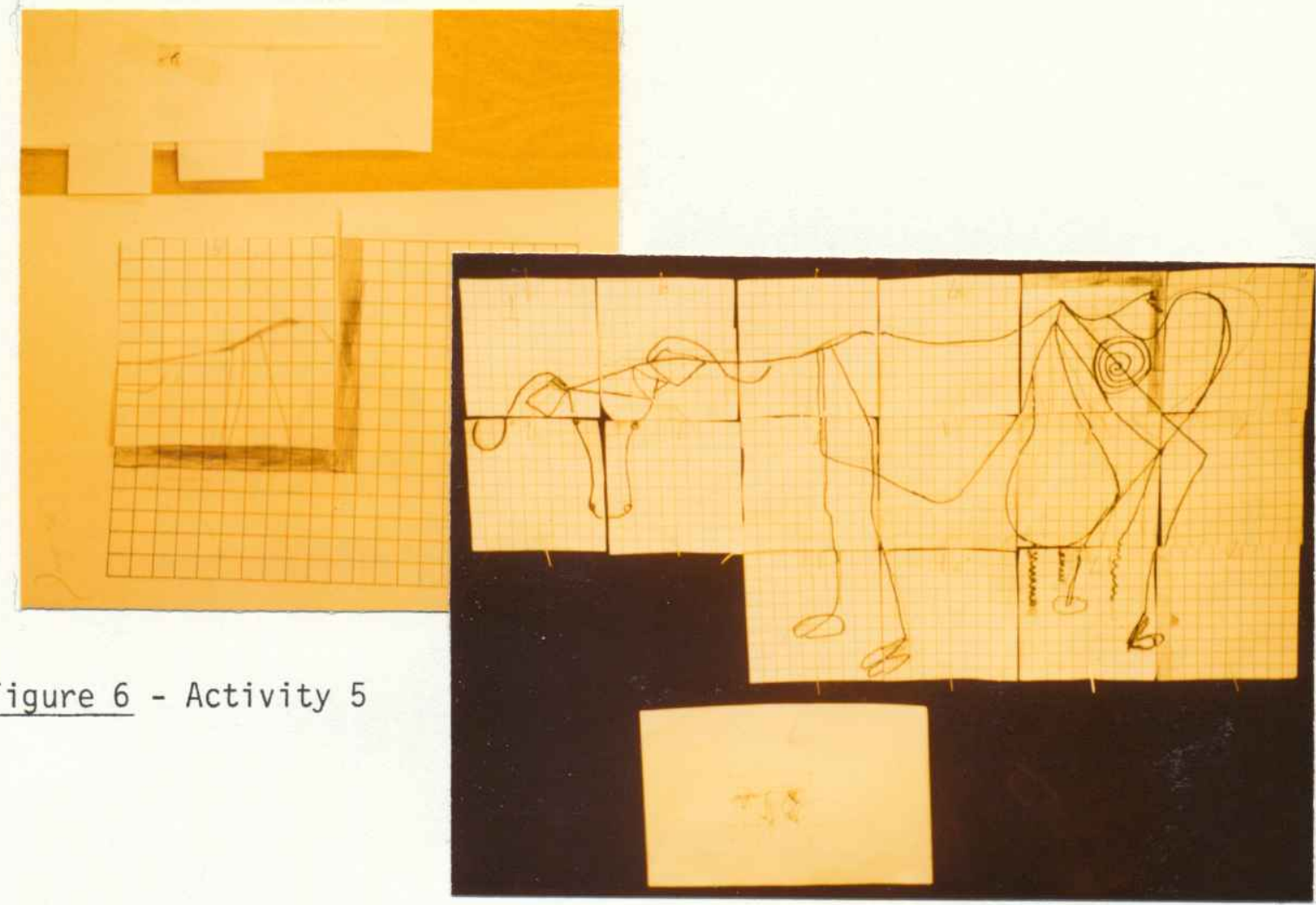

Figure 7 - Activity 5 (continued)

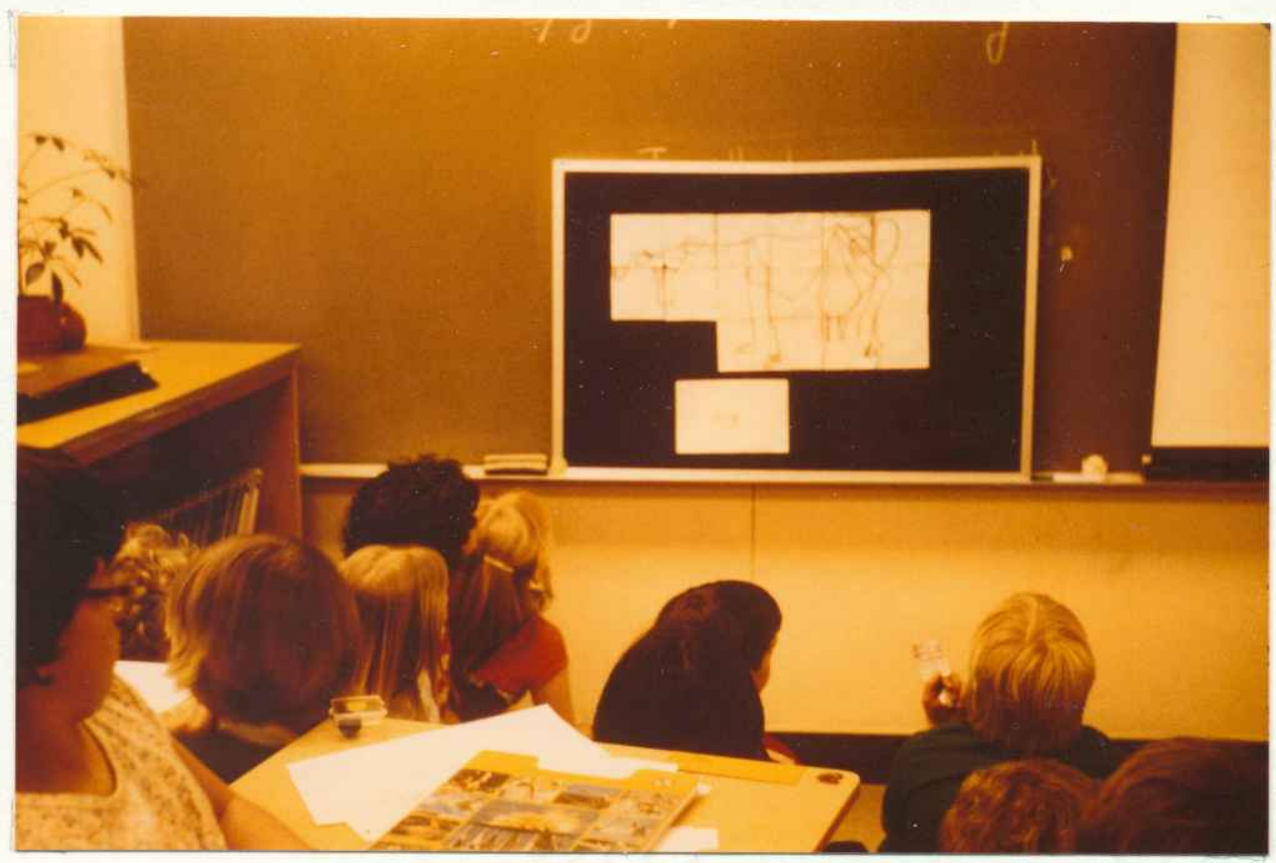

Figure 8 - Activity 5 (continued) 
31

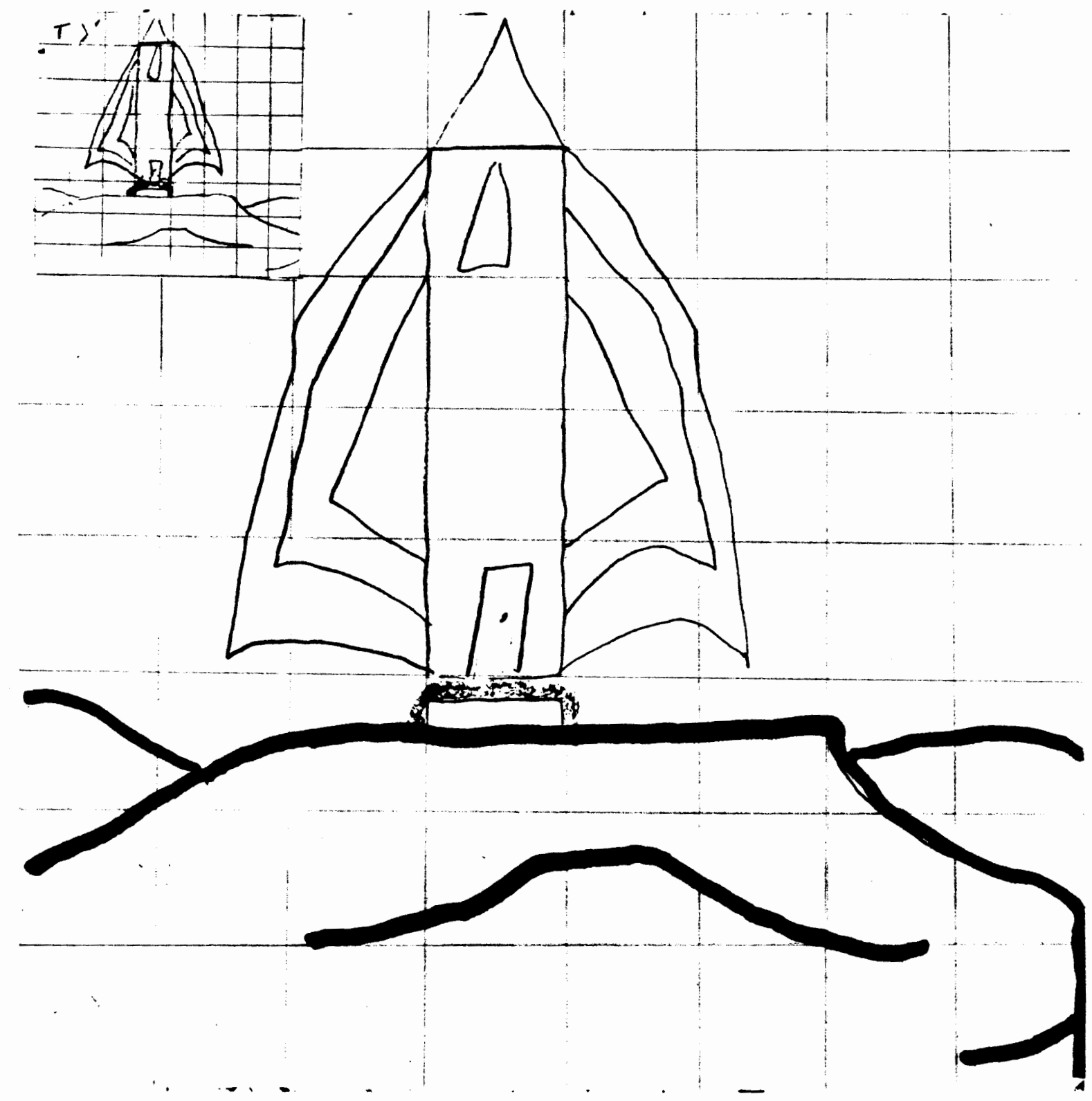

Figure 9-Activity 7 


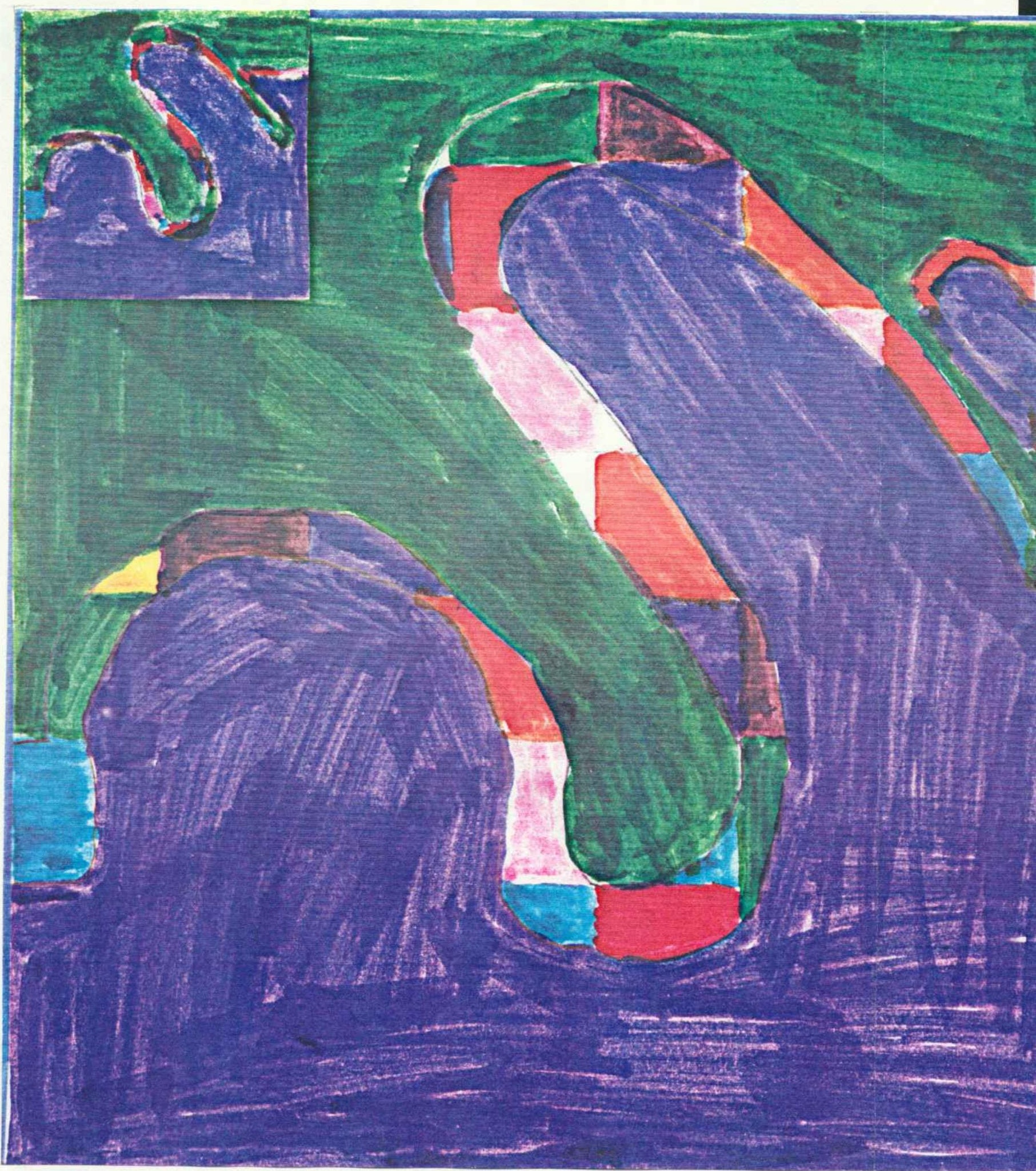

Figure 10 - Activity 8 

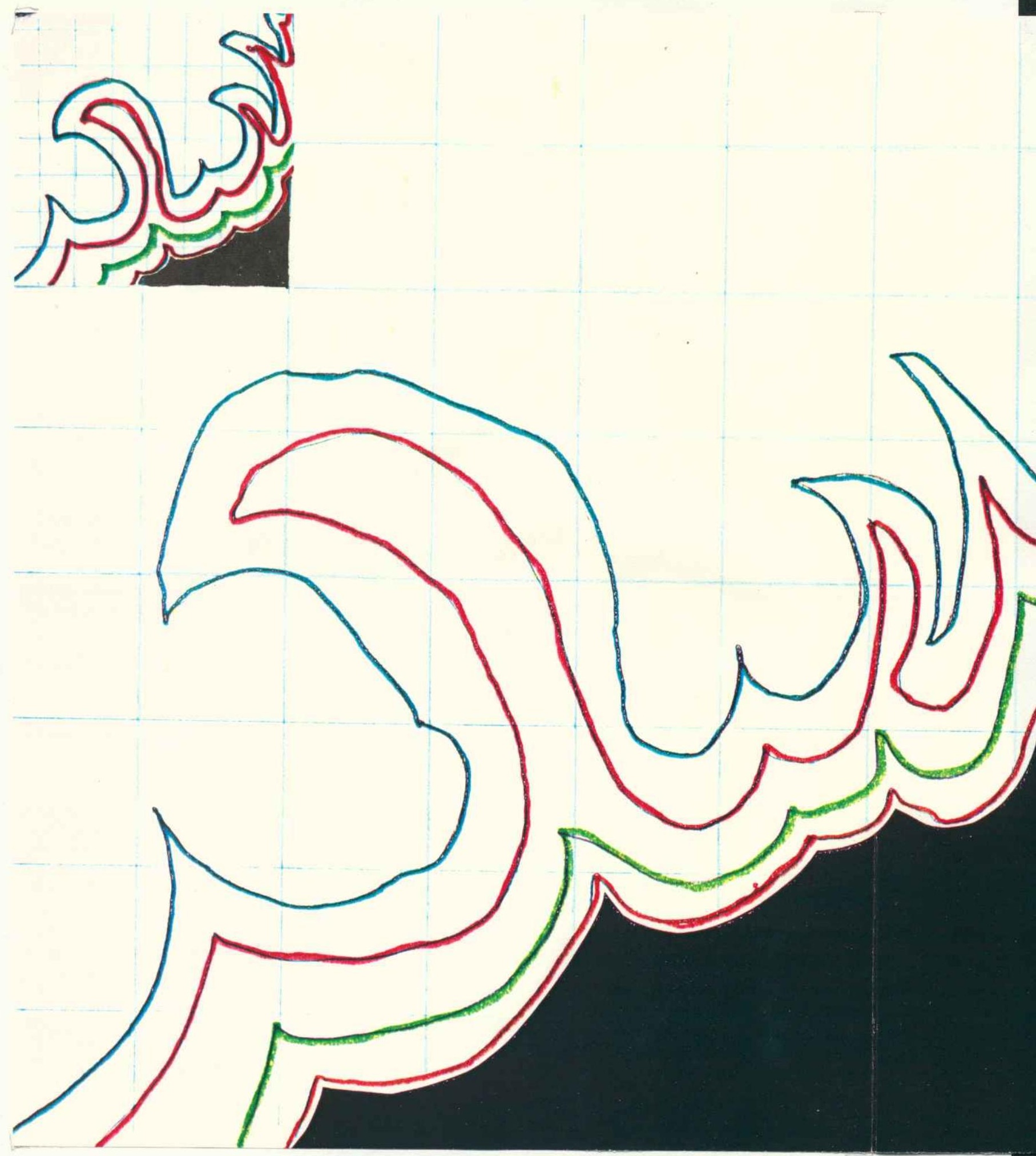

Figure 11 - Activity 8 (continued) 


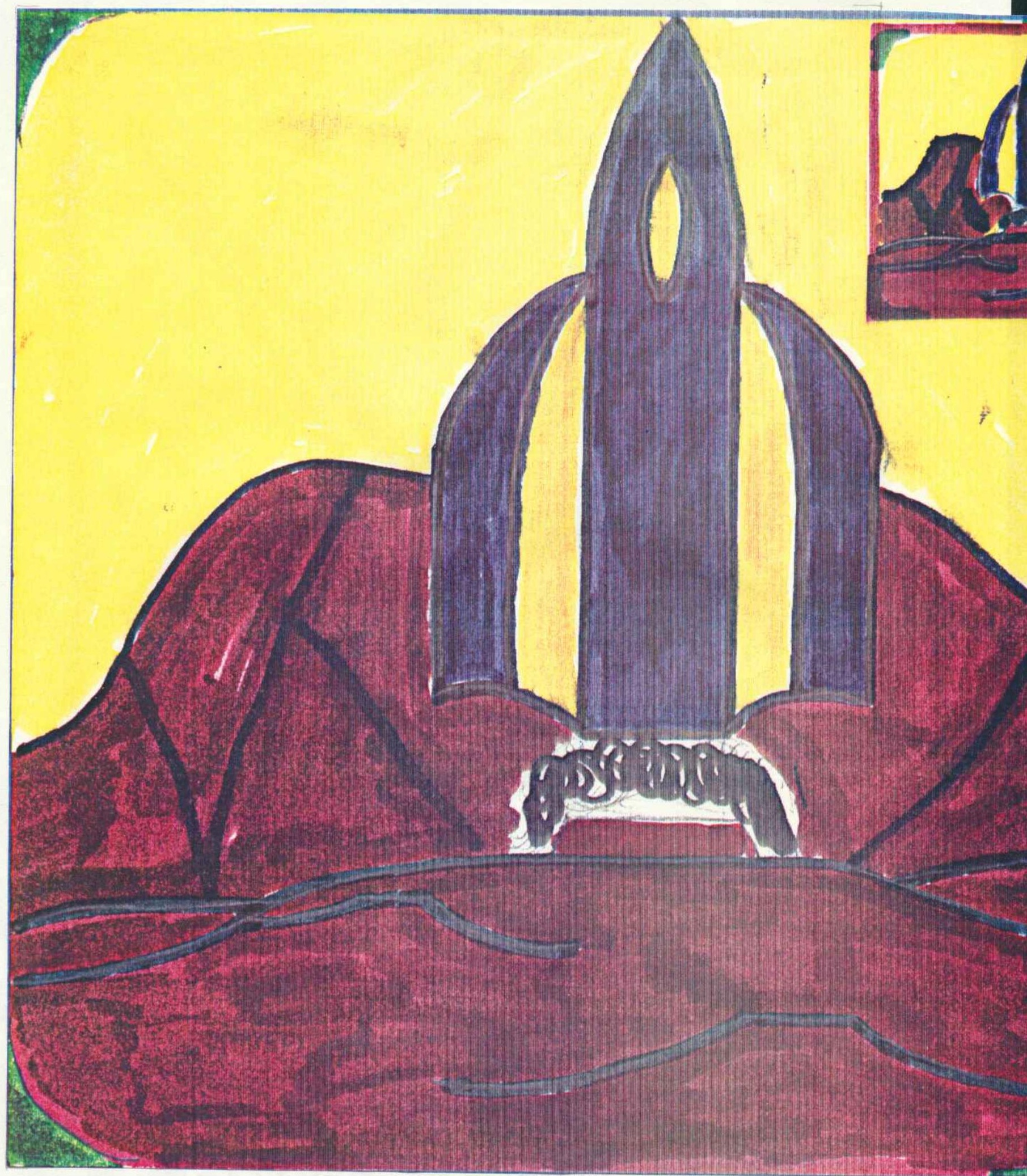

Figure 12 - Activity 8 (continued) 


\section{PROJECT II \\ ART AND TALENTED AND GIFTED}

The second project also examined the relationships of art and science. This time I started with the premise that "creativity is an aspect of intelligence" 35 and that "creativeness in the arts and in the sciences has common attributes"36. I therefore concentrated my attention on the Talented and Gifted (TAG).

I would like to see the TAG program pay more attention to the artistically and creatively gifted. The lack of it stems possibly from the limitations of present methods used for the identification of the talented and gifted children.

Even though many $\mathrm{claim}$ to know better, schools often still cling to the traditional methods of testing. Most aptitude tests currentiy in use measure only the IQ, which is just a part of the overall scope of intelligence. Thus TAG program may overlook many naturally creative children who do not score highly on IQ tests. Yet, under favorable conditions, they learn as well as those with high IQ.37

In a study done on scientific qualities in scientists, researchers found two "unrelated quality ratings": 1. high level academic quality without originality, 2 . originality type quality 38 .

35 Burton, p. 19.

${ }^{36}$ Research in Art Education, p. 43.

37Paul E. Torrance, Guiding Creative Talent (Englewood Cliffs, N.J., 1962), pp. 4 \& 5 .

${ }^{38}$ Calvin W. Taylor, "Research Findings on Creative Characteristics", Creativity and Art Education, p. 31. 
I am afraid that if we do not change our present system of identifying the talented, we may impair or lose much of the second quality originality. The only solace in this situation is that if we accept that creativity can be developed, a knowledgeable and creative teacher can help to identify and bring out these qualities in children.

I have had a chance to meet such a teacher who works with a group of TAG children ranging in age from second to sixth grade. I observed her group for two weeks before interjecting an art lesson which would be designed to be relevant to the subject of their study.

They studied nutrition, a large unit under which heading they pursued a wide variety of activities. The teacher utilized the inductive process whenever possible, giving the children chance to explore, test, and draw their own conclusions. They collected specimens, grew cultures, observed them under microscopes, and learned to make inferences on the basis of their own findings. This approach was combined with independent research in the school library. The results of all of this were individual presentations to classmates.

I wondered, though, to what degree children can observe the minute details necessary for correct visual comparisons and later inferences. I thought of Frank Openheimer, who expresses his view on the connection of observing and synthesizing between the arts and the sciences:

I think there are some parallels between what artists do and what scientists do. They both start noticing things. Much of the noticing of things that fit together in physics, as in art, is intuitive. 39

${ }^{39}$ Arts Education and Back to Basics, p. 34. 
And Landis stresses that: "Intuition is the product of a long incubation of observation and imagination." 40 The observational skills also have to be developed, and art is the best instrument for it.

Art education, properly presented, awakens the child's sense of observation so that he possesses a seeing eye and an understanding mind. The act of seeing involves the process of thought, of memory, and of judgment.41

Things observed under microscopes provided an excellent source for an art activity, so when the children were ready to explore blood more deeply which involved the examination of their blood samples under the microscope, we included an art lesson.

It was planned in two parts. The first took place before the children saw the actual blood samples. They were supposed to express visually their expectations of what they thought they would see. In other words, their hypotheses were made on the bases of their present knowledge about blood. It was a new way of presenting their hypotheses other than in words.

We used regular $81 / 2 \times 11$ inch sheets of light-weight drawing paper, watercolor markers, brushes and water containers.

Before the children started to draw, we reviewed their knowledge of blood: e.g., what they knew about the compounds of blood cells, cell shapes, sizes, and colors, and what they remembered from their past experiences from looking into a microscope. We also discussed some of the aesthetic choices they had in expressing their ideas so that the result would be both informative and visually pleasing. This involved

40 Landis, p. 49.

4l Leon Loyal Winslow, The Integrated School Art Program (New York, Mc Graw-Hill Book Co., 1939), p. 11. 
discussion of such design elements as line, shape, proportion, composition, contrast and color. To make the rendering possibilities more interesting for them, I introduced them to a wash drawing, a new technique for them in working with watercolor markers. Most children resorted exclusively to a choice of a red color, a few used also blue or brown, and only one girl produced a full color picture (Figure 21).

The second part of the art sequence corresponded with the actual observation of the blood samples under the microscope.

Each student's task was to be a keen observer and draw what he/she saw. The drawing was to be the report of their immediate observation. When we compared the two kinds of the drawings, that is the hypotheses with the actual studies, we found that they did not differ much from each other (Figure 13-22). The natural assumption would be, that the children did a good job on their expectations. However, if we look beyond the superficial appearance, the conclusion is not that simple.

A careful observer can notice that most of the hypotheses are on the whole better executed, showing more involvement by the children (Figure 15, 17, 21). Apparently they had more difficulty in dealing with the reality, which might have been visually too complex for them to handle with their limited skills.

This discrepancy is more understandable in the third graders who, according to Lowenfeld's developmental stages, could be still in the schematic stage. 42 I say could be, because I would assume that with

\footnotetext{
42Lowenfeld, p. 37.
} 
their high intelligence quotient, they would be developing faster in other mental capacities as well.

Generally, fourth and fifth graders are expected to have reached the stage of visual realism, a period in which their perceptions of reality should be getting sharper with greater attention to details. 43 The fact that they did not show any great fluency in graphically handling their visual observations suggests that in the course of the overall educational process they have not received enough stimulation and direction in the subject of visual observation and eye-hand coordination; their perceptual and expressive skills may not be developing in equal proportion with their intellect. They may lack skills in observing and comparing details and in graphical expression of their observed subject. They may lack the patience necessary for carrying out a project which involves all of those skills mentioned above.

In the first art activity - the representation of their expectations - the students started to rush through the project, not developing their ideas carefully and being quite satisfied with just a rough sketch. I had to slow them down by making them pay more attention to the design elements and by emphasizing that they were entitled to be interested in any other part of the process. Had they been used to art experiences, they might have been more able to express their perceptions with much greater ease and enjoyment and not necessarily been so satisfied with an early product.

$$
{ }^{43} \text { Ibid., p. } 38 .
$$


However, the realization of the potential importance of art to the enhancement of learning in their academic endeavors is the first step toward practical implementation of art in school programs. That such awareness has been achieved here is indicated by the statement of the teacher in her letter to me: "Aside from the intrinsic value of the lesson, the students learned a new artistic technique and became more aware of the useful function of art in many academic disciplines."

The experience of these two related projects suggests that all children, whether in regular class or in the TAG program, can benefit from meaningful art experiences. They can learn to accurately observe, to handle materials, to make effective aesthetic choices in expressing their ideas, and also they can learn the patience and self-discipline necessary to bring their projects to successful conclusions. And I would venture even further by suggesting that highly intelligent children may especially need such experiences to offset some of their natural impatience with themselves, their frequent unwillingness to repeat a similar activity and their tendency to rush forward without developing the needed skills by which they establish solid ground for their later endeavors. 


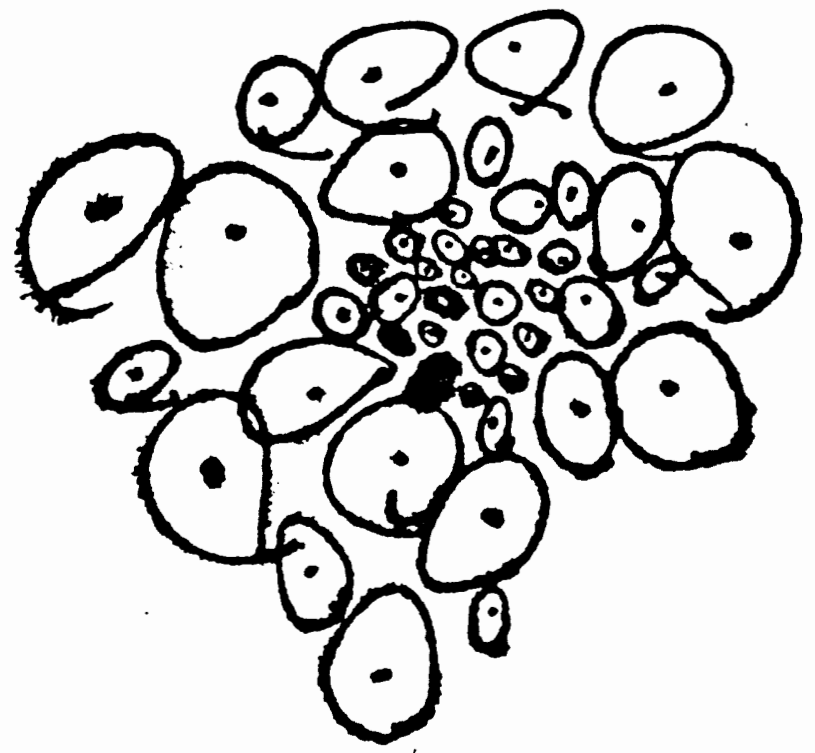

Figure 13 - Hypothesis by D., 3rd grade

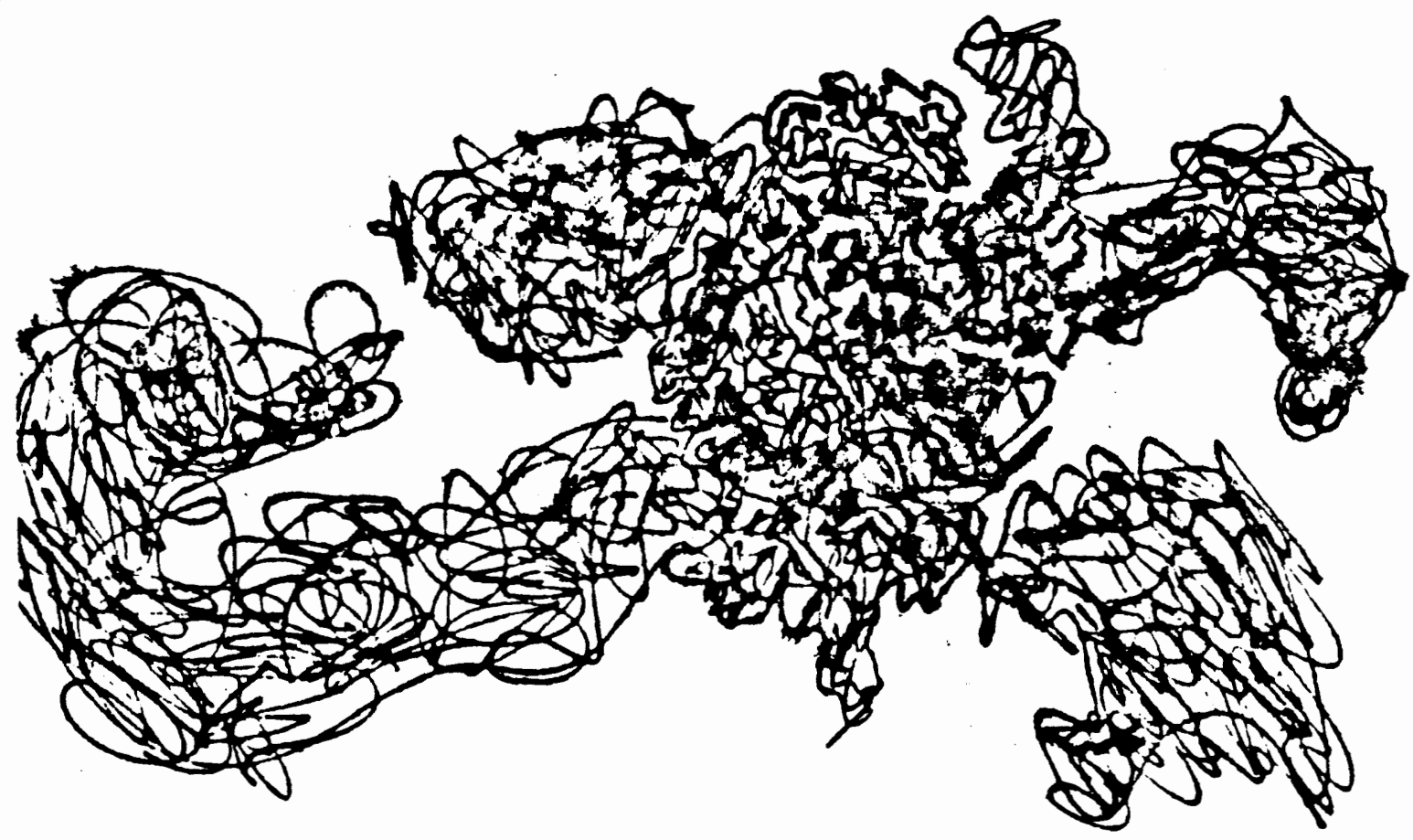

Figure 14 - Result of the actual observation by the same student 


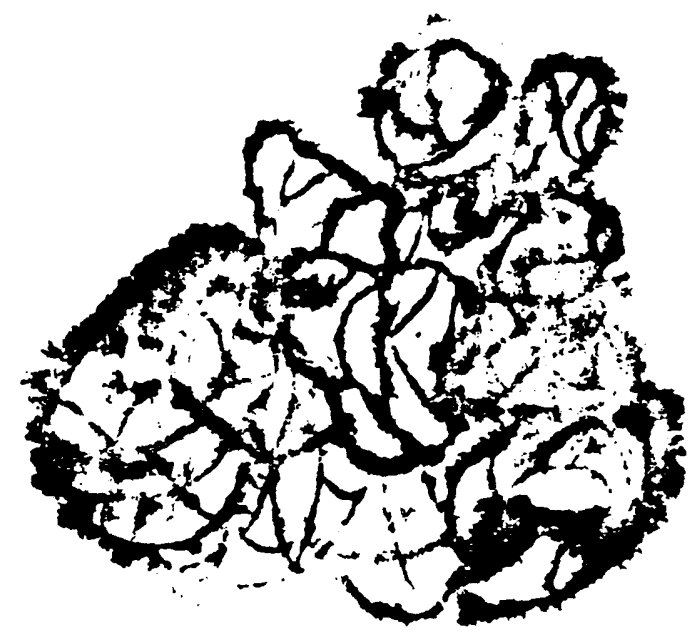

Figure 15 - Hypothes is by J., 3rd grade
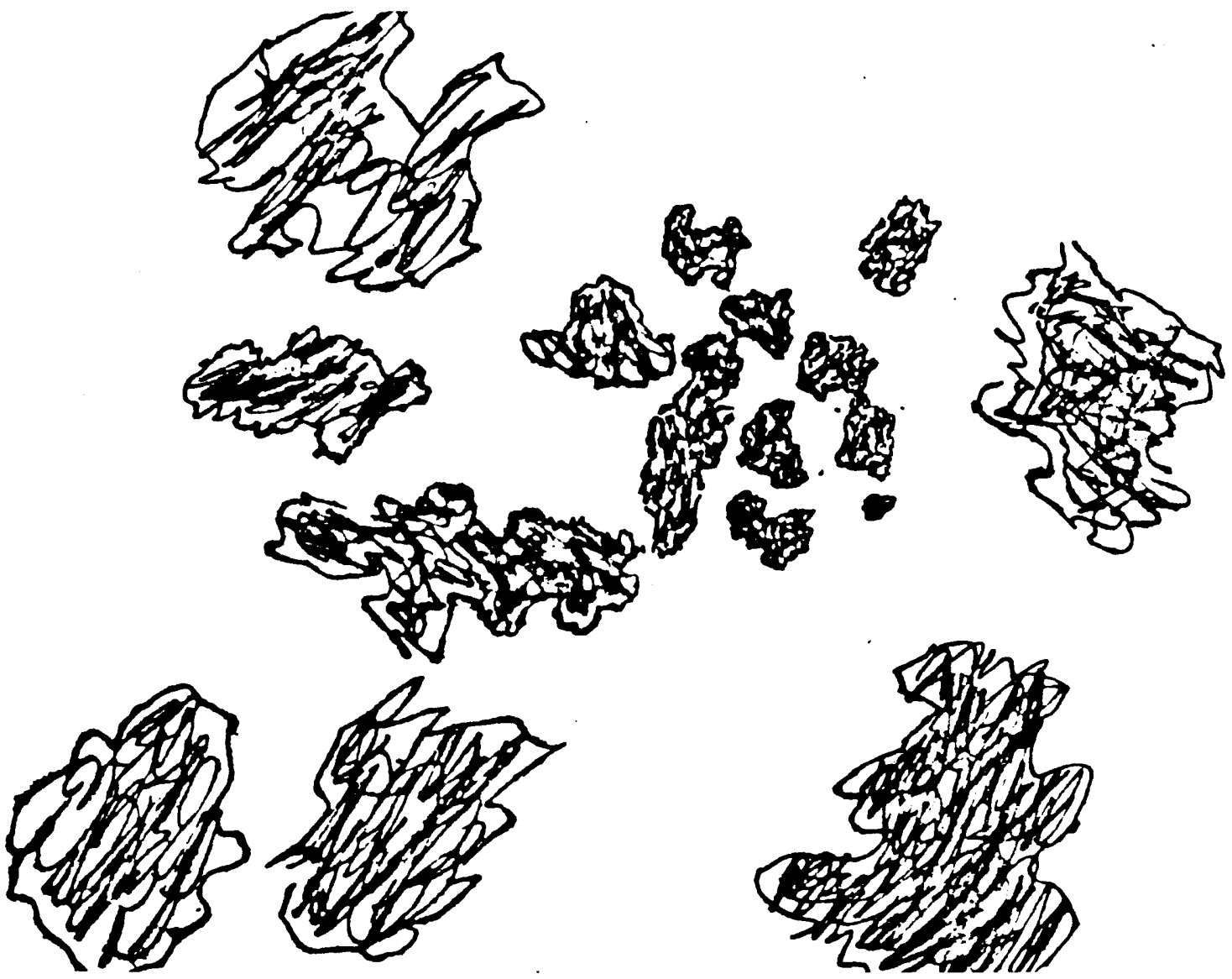

Figure 16 - Result of the actual observation by the same student 


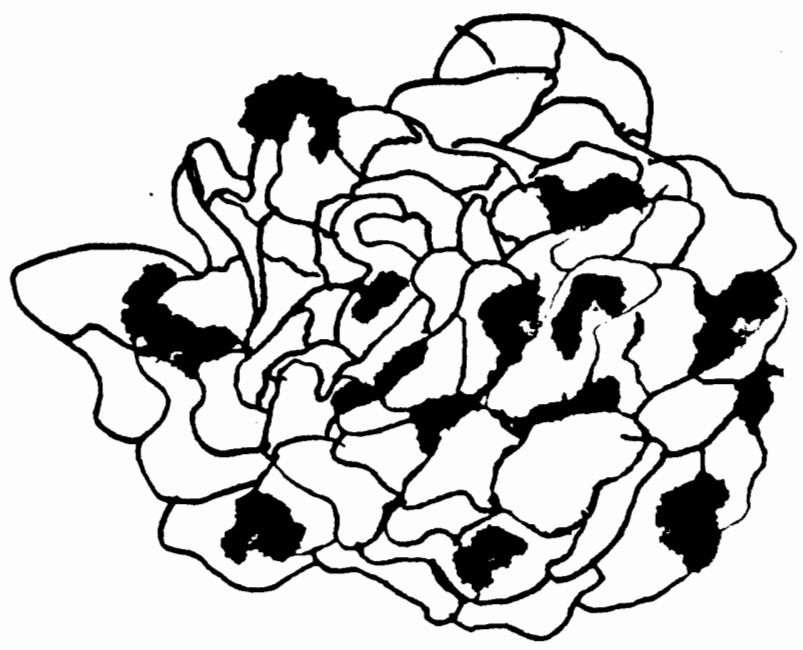

Figure 17 - Hypothes is by L., 4 th grade

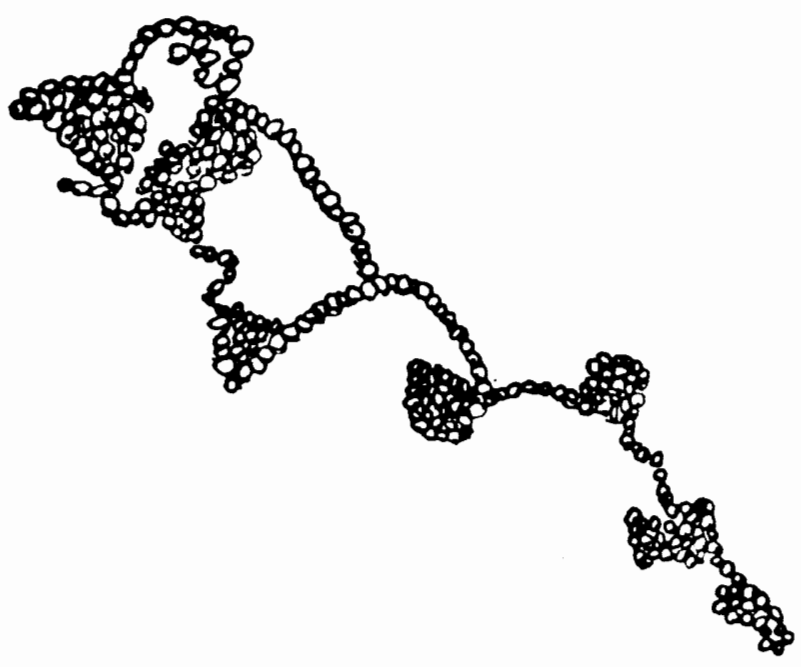

Figure 18 - Result of the actual observation by the same student 


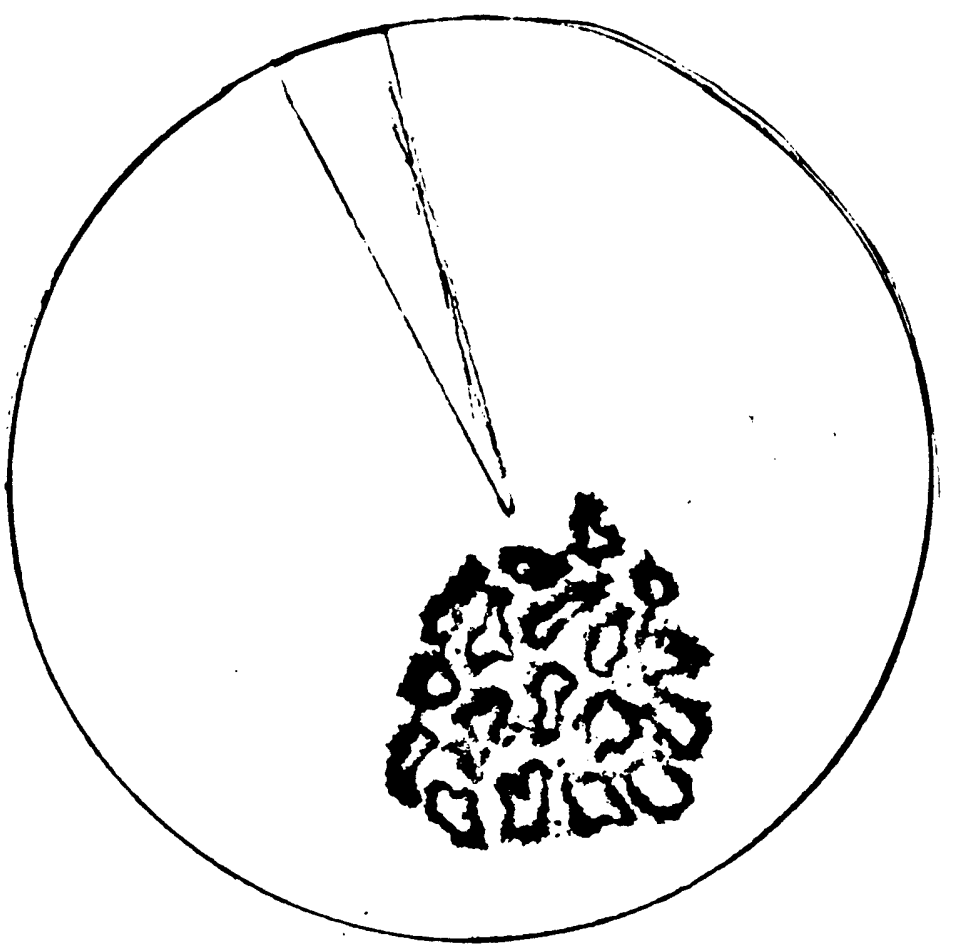

Figure 19 - Hypothesis by M., 5 th grade

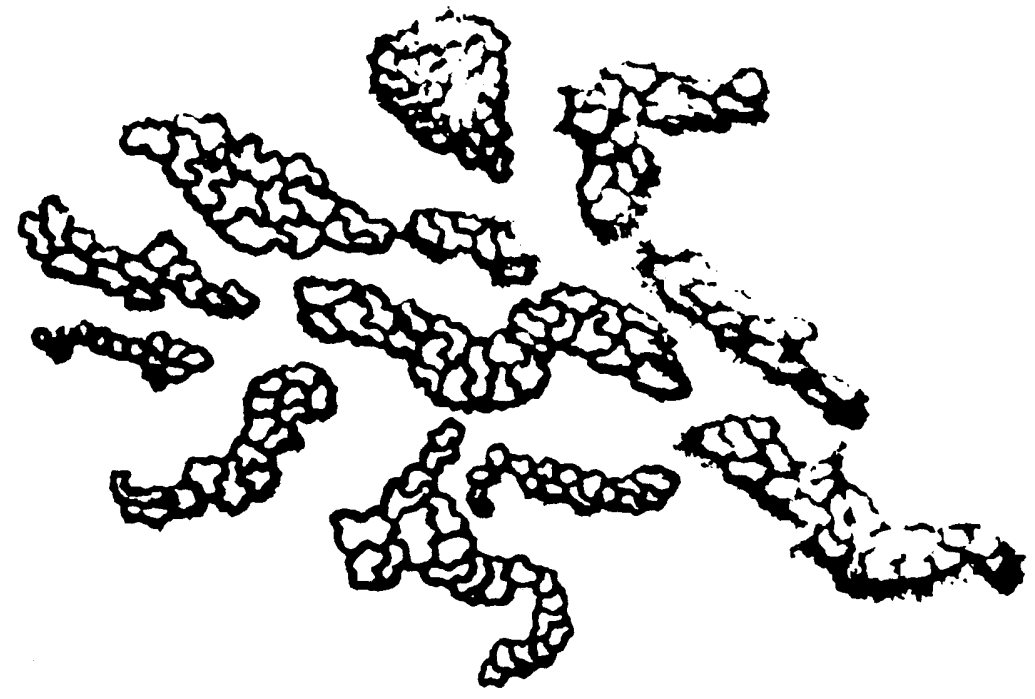

Figure 20 - Result of the actual observation by the same student 


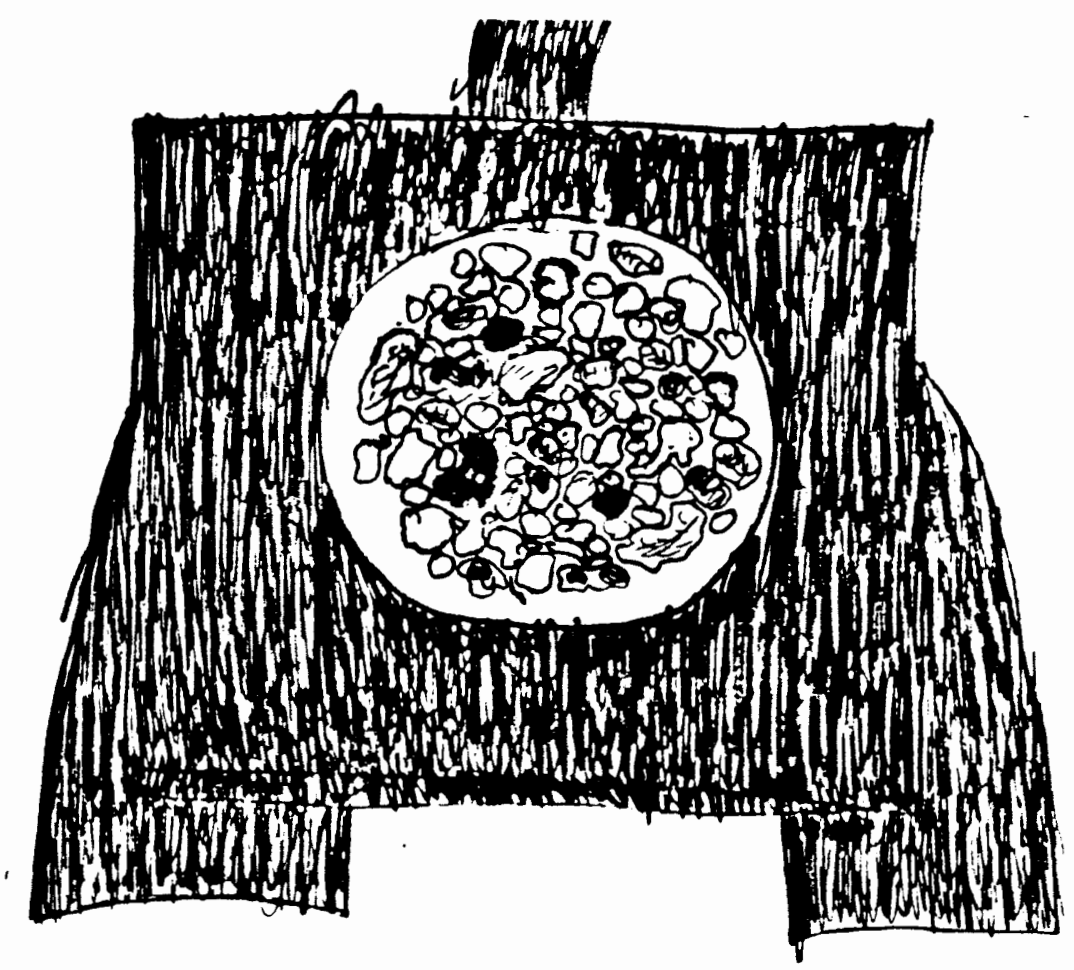

Figure 21 - Hypothesis by J., 5 th grade

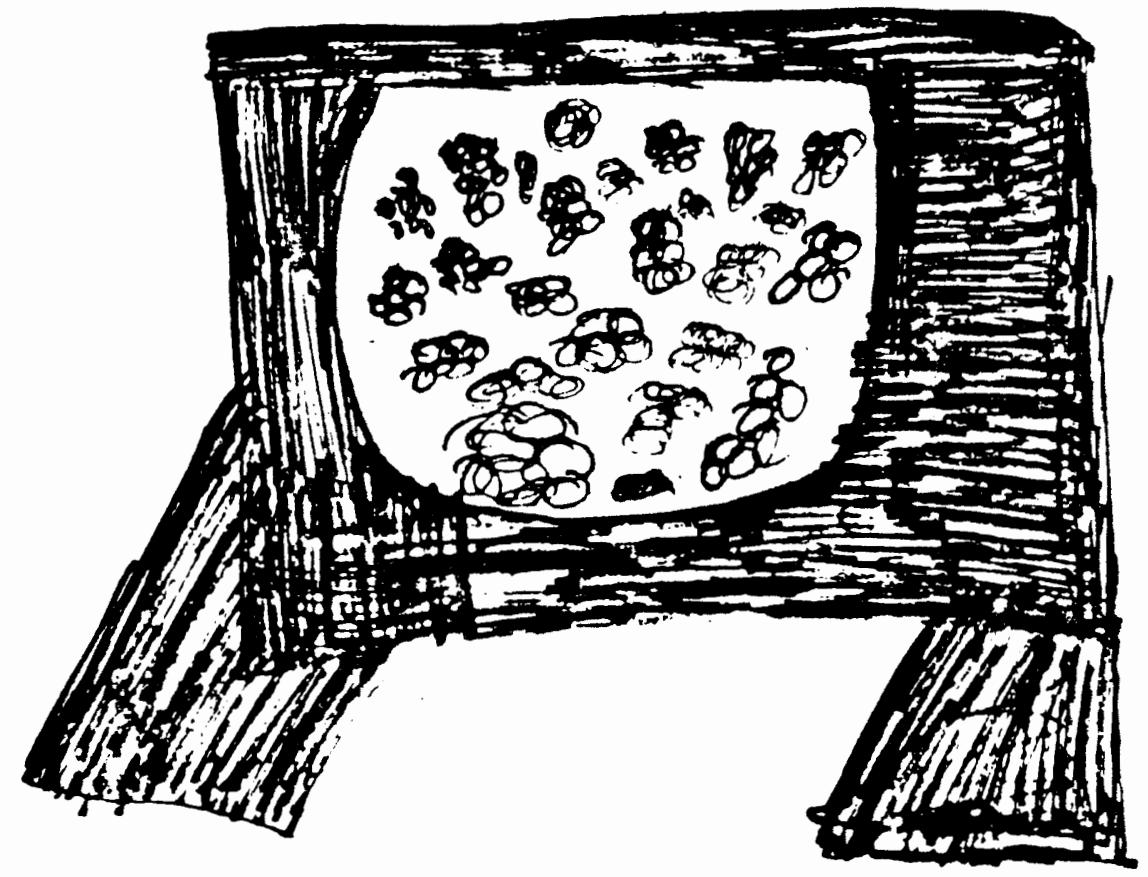

Figure 22 - Result of the actual observation by the same student 
PROJECT III

\section{ART AND LANGUAGE ARTS}

The third project evolved from a situation not originally planned for this study. A teacher friend asked me to come to her fifth grade class and give the children a short lecture in Czech, my native 1 anguage.

The class had a new pupil, a Vietnamese girl, who spoke very little English. The teacher wanted to make the children aware of the girl's communication problem and to arouse empathy for her situation.

I suggested the use of an art experience as an experiment and the teacher agreed. The experience was to be a part of social studies, with following set of objectives:

1. To stimulate in students an awareness of how an individual deals with language barriers.

2. To observe other methods of communication besides verbal.

3. To influence positive attitudes toward the Vietnamese student in the class.

These objectives were very closely related to the objectives of art lesson I had been preparing:

1. Observe your own feelings when you don't understand the language spoken to you.

2. Identify other means of communication besides verbal.

3. Express your own experience in creating a picture.

To heighten the emotional charge of the experience, I came to the class in a mask made out of aluminum foil and painted with acrylic 
paints (Figure 23). I talked in Czech for about 3-4 minutes, asking the children to "draw what they see and feel". To ease the frustration and to enhance their awareness of body language, I gave them some clues. I took for instance, a crayon and pointed to the drawing paper they had prepared on their desks.

Then I took off the mask, switched to English, introduced myself and began a short discussion on how the children had felt at the moment, how much they understood and why, and of what kind of communication had they been aware. I repeated the art project requirement in English. The title of the project was The Stranger in our Class. I wrote the title on the blackboard and under it also the Czech translation, Cizinec $v$ naši trídè. We even tried to pronounce the Czech words with class for the experience of different sounds of speech and how they are formed. Before the children started their drawings, we discussed the visual possibilities they had for solving the task. For instance they could have concentrated on the mask, or draw the mask and the person hiding behind it, or involved themselves and their friends in the picture. I also made some suggestions on the design elements they might use, stressing utilization of the format. We talked about the treatment of space perception and of the simple figure proportions. I emphasized that it is important to incorporate their feelings into their pictures.

At first the children were uneasy, needing time to recover from the initial shock and to cope with their feelings and identification of them.

But after a couple of minutes as they became involved in the project, some interesting ideas started to take shape (Figures 24-28). 
For instance, one boy, working on a completely abstract design, said: "This is how I feel". Unfortunately, he changed his mind later and, abandoning his initial inspiration, he gave in to the more typical mode of expression. One girl developed a complex symbolic vocabulary to convey her feelings and perceptions of the stranger. Her design was not very pleasing (perhaps due to her undeveloped aesthetic skills) and did not allow her to organize her complex thoughts effectively. Her personal visual expression attempt, however was impressive.

Another boy showed well developed perceptual skills by depicting the mask and a face peering behind it, both in well defined shapes. He proved that he knew what he was after, when, not satisfied with his first attempt because of the awkward spatial relationships of the two shapes, he made a new drawing in which he corrected the previous error (Figure 28). Yet, his teacher told me that this boy has a problem of organizing his thoughts. However this episode disclosed, rather, that this boy may need a different method of teaching. He may process information in different ways than the prevailing instruction, based predominantly on the language mode, emphasizes.

Only toward the end of the session did the children begin to verbalize their feelings, ask inquiring questions and guessing why the lesson was conducted that way. We heard comments such as: "Now I know, why you came in the mask and talked to us in Czech. You wanted us to know how it feels when we cannot understand." Or: "Now I know, how T. must have felt the first time she came to school."

In the next session they were able to express their reactions in short written paragraphs. 
Because of the success of the experiment with the art experience as a catalyst to the children's feelings and awakened empathy for T. and because the children and the teacher liked my mask and wanted me to come back and make it with them, I suggested a following sequence which the teacher accepted with enthusiasm. First, the teacher was to apply this experience with a stranger to creative writing and then I would come back and help the children make their own masks, which would represent the heroes of their stories.

Unfortunately, the teacher did not realize the significance of the time element in the relationship of the experience to the creative process. She let two weeks elapse before asking the children to write their stories about a stranger. By then the intense feelings and possible images associated with them had dissipated. In some of the stories we could still find an echo of the initial first hand experience, but in most of them the influence of other media, especially TV, had become a primary influence.

Thus, a unique opportunity to examine the direct influence of art on language arts was lost.

However, there is one point which must not be overlooked. All the stories revealed an understanding and an acceptance of the stranger which I think can be directly tied to the impact of the first session.

The next activity in this sequence was to make the masks. The materials needed was: heavy duty foil (14 inch square for each student); acrylic glossy media; acrylic paints; flat brushes; foil pans to hold the paints; newspaper strips for paper-mache (or kleenex, which 
is more absorbent); water containers; scissors; couple of staplers and a bundle of old newspapers to cover the desks.

As an introduction we had a discussion about masks, rituals, hidden identity etc., illustrated by photos of African, Melanesian, and Indian masks. We compared face and body painting of some tribes with mask customs of other tribes. We also mentioned Romeo from Shakespeare's Romeo and Juliet and why he wore a mask at the ball. Finally we arrived at our own time and our own society discussing such rituals as Halloween as well as the behavior of people who put on masks of certain expressions to hide their true feelings.

In this way we brought the art activity back to the connection with social studies and established a wider base of understanding of the significance of mask making.

Furthermore, while looking at the pictures of different types of masks, the children's attention was called to the ways the various designs were handled.

Then, after a short demonstration with explanation of the process, the children started to work independently on their own designs. First, they shaped the aluminum squares over their faces and cut the essential holes, gaining the basic form of the mask. In this step they were encouraged to work in pairs to help each other.

After that each child worked on his own with occasional advice or suggestion from the teacher. Some children were ready to paint their masks immediately (Figure 31 ), while others first altered the basic shapes by building them up with layers of small pieces of paper bound 
together with acrylic glossy media (Figures 29, 30). The attractive vibrance of such a painted surface is due to the acrylic medium into which small amount of acrylic pigment is mixed. Applied in thin layers it turns transparent upon hardening, allowing the shiny aluminum base to illuminate the applied colors (Figure 32).

The children enjoyed this activity tremendously judging from the zest with which they worked on their project. Because of the fairly fast and easily-developed basic form, the children were encouraged by their initial success and could focus their attention immediately on the decorative process. Even so, we needed two sessions to finish the product.

The last part of the sequence, at the initiative of the teacher, involved sharing the masks and the stories with the class.

In summing up this project I must admit with regret that due to the wrong timing we were not able to establish more measurable evidence of the influence of art experience on the language arts. However, the teacher, herself, expressed excitement about the possibilities of combining art with other learning processes.

The essential value of such experiences and interconnections for quality of education is obvious. 


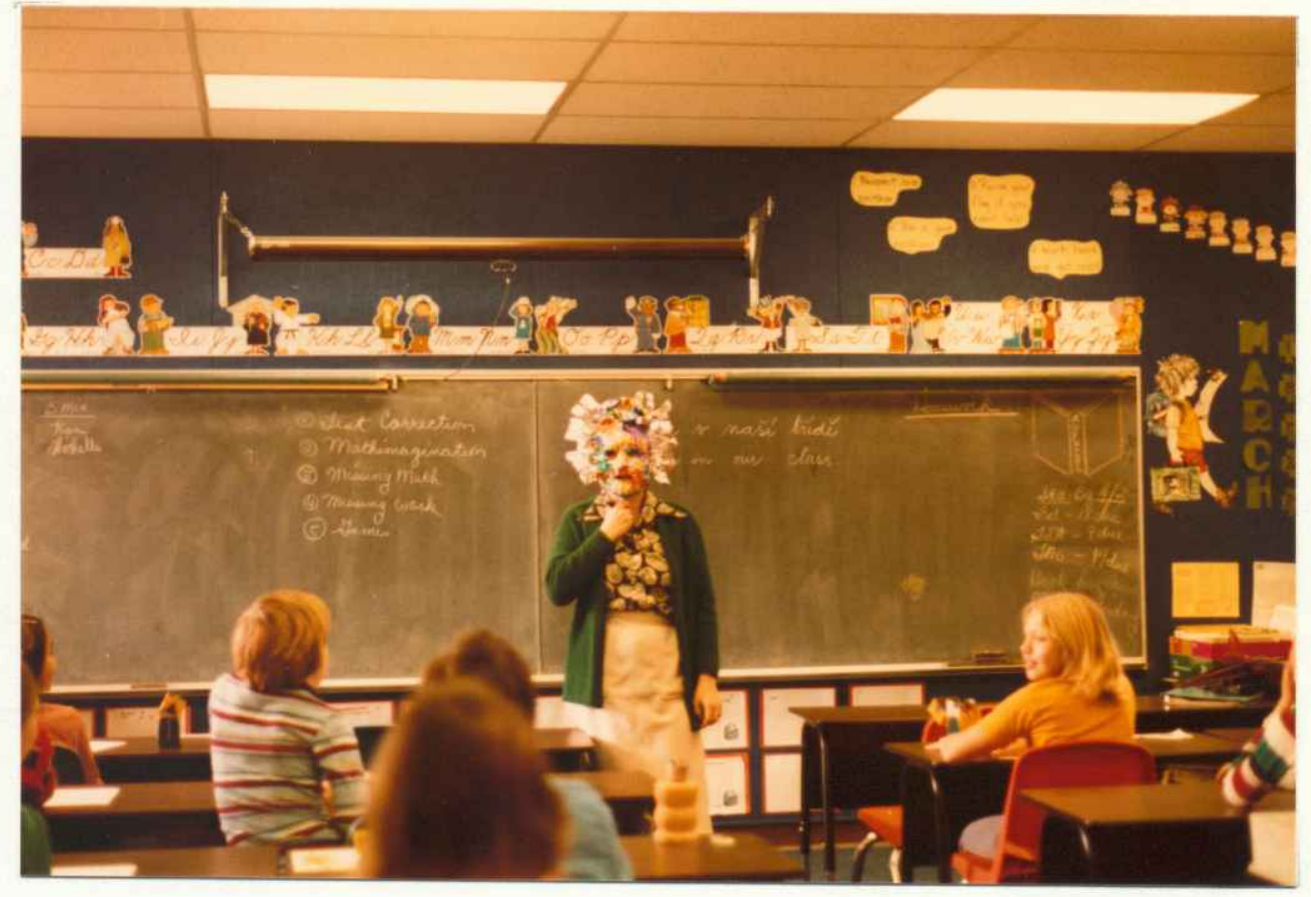

Figure 23 - "Stranger in our class"

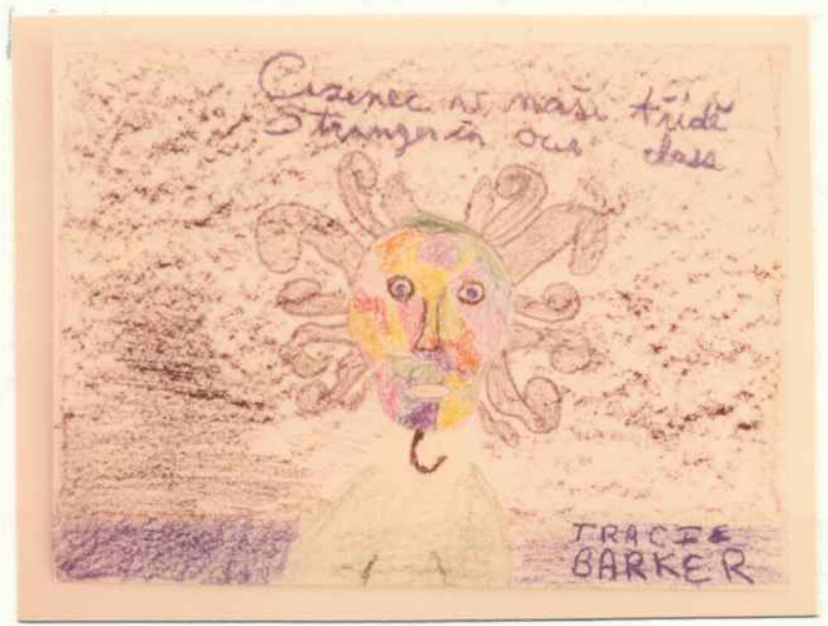

Figure 24- Student drawing 


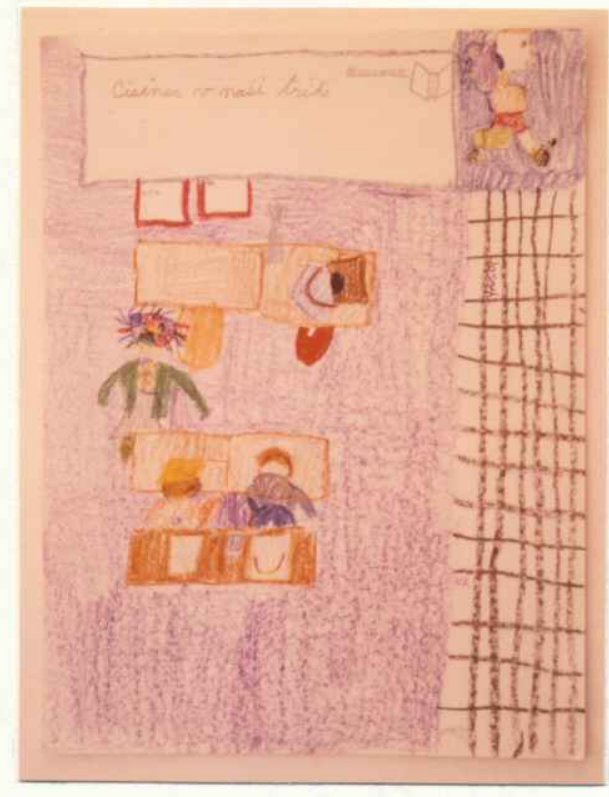

Figure 25 - Student drawing

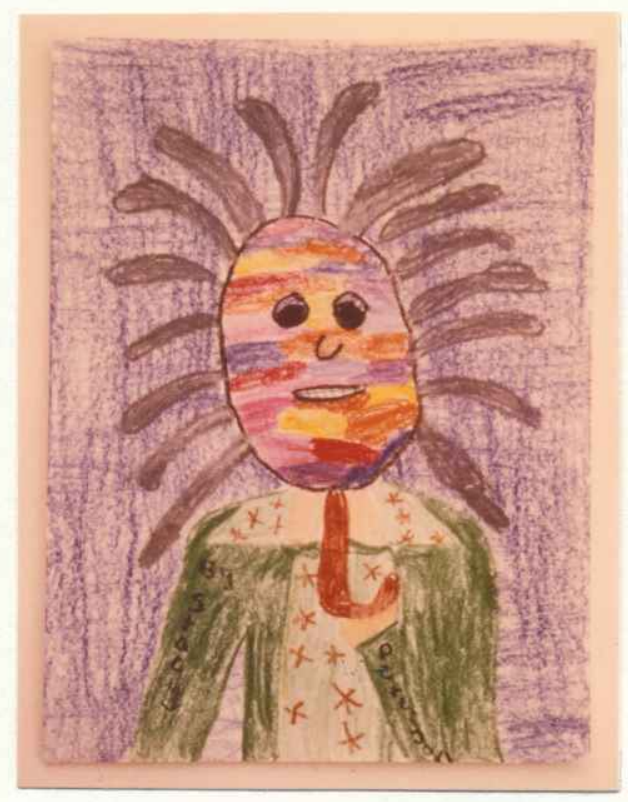

Figure 27 - Student drawing

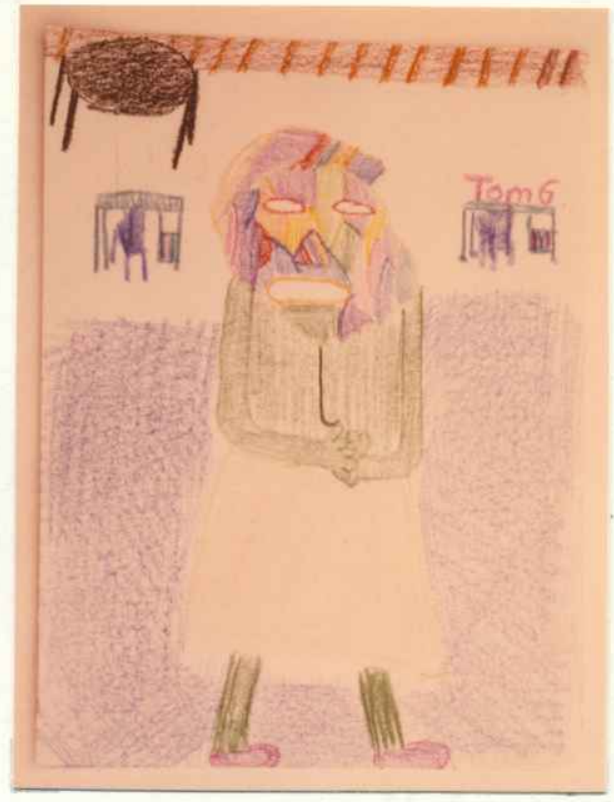

Figure 26 - Student drawing

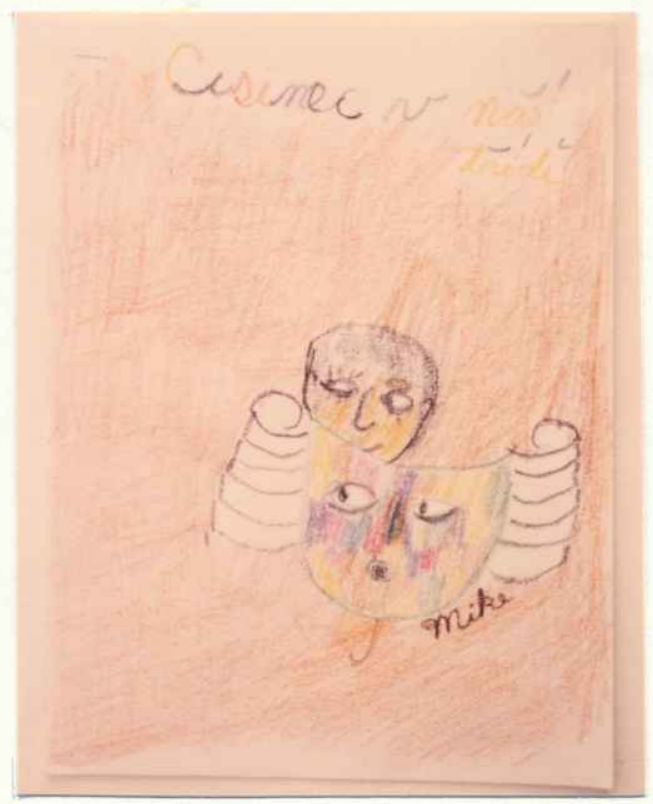

Figure 28 - Student drawing 


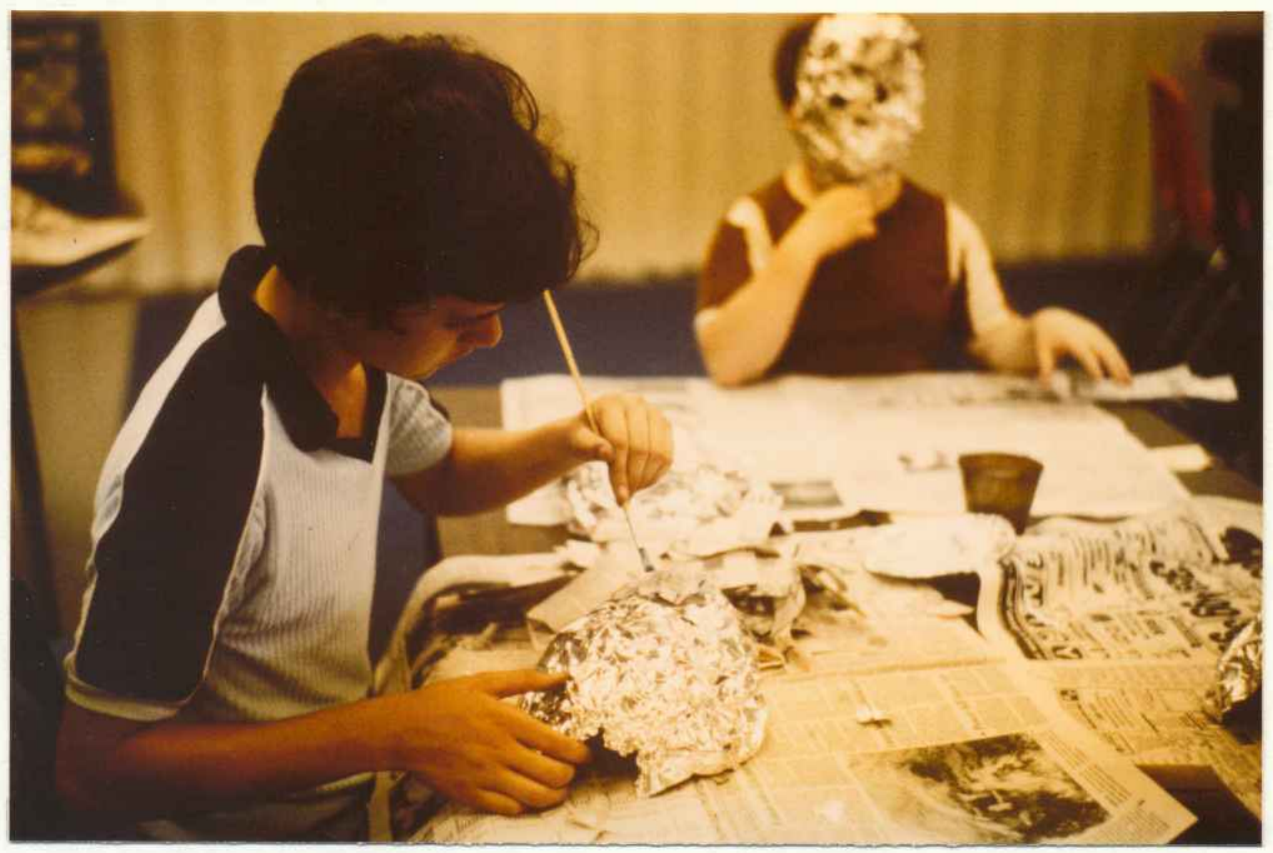

Figure 29 - Mask making

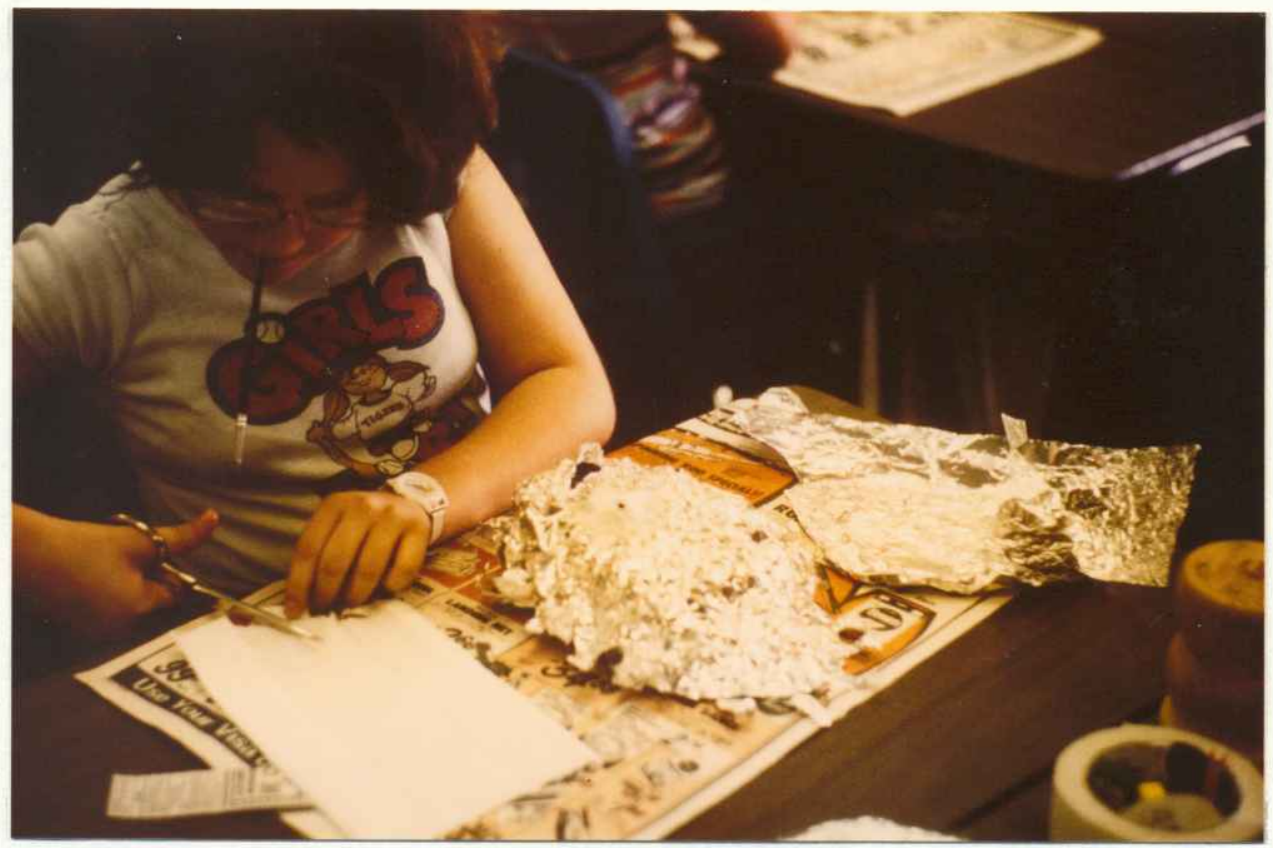

Figure 30 - Mask making 


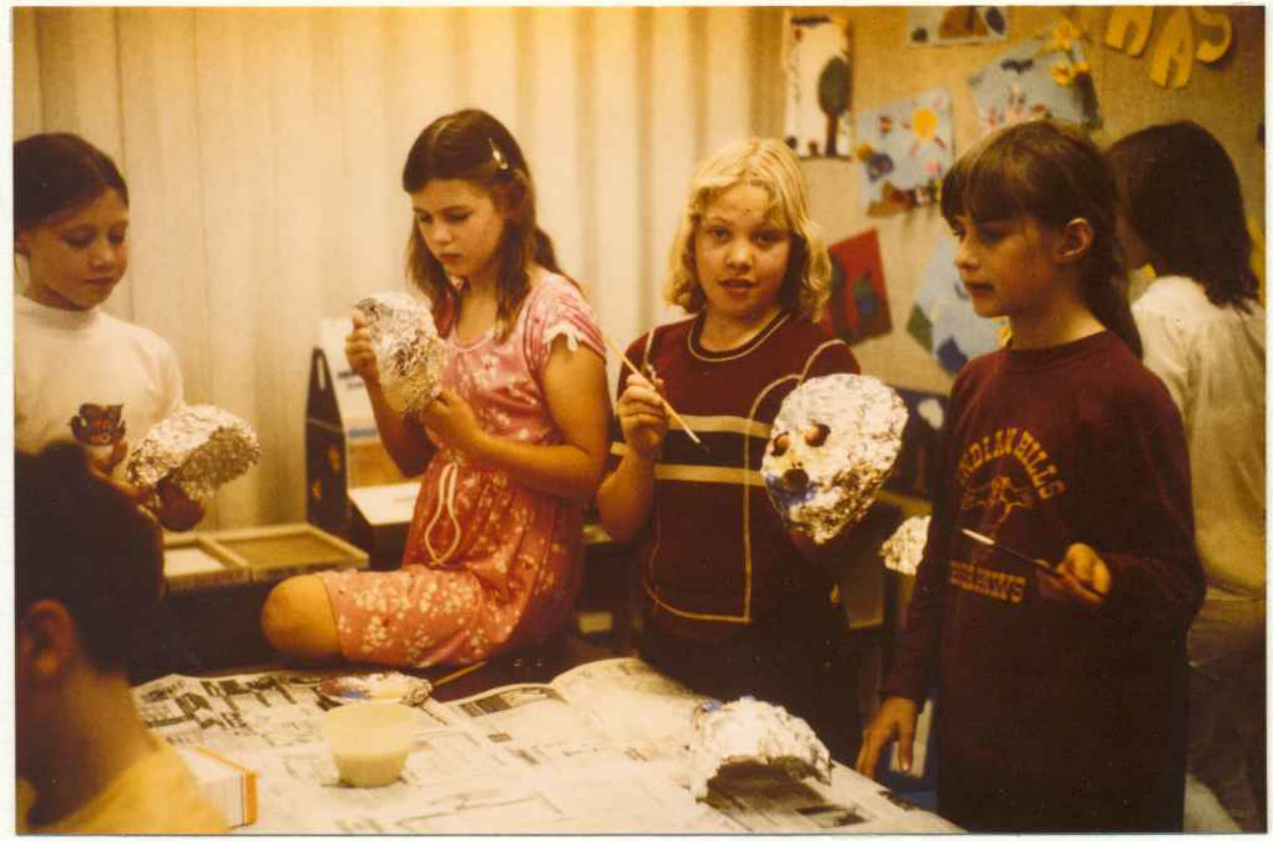

Figure 31 - Mask making

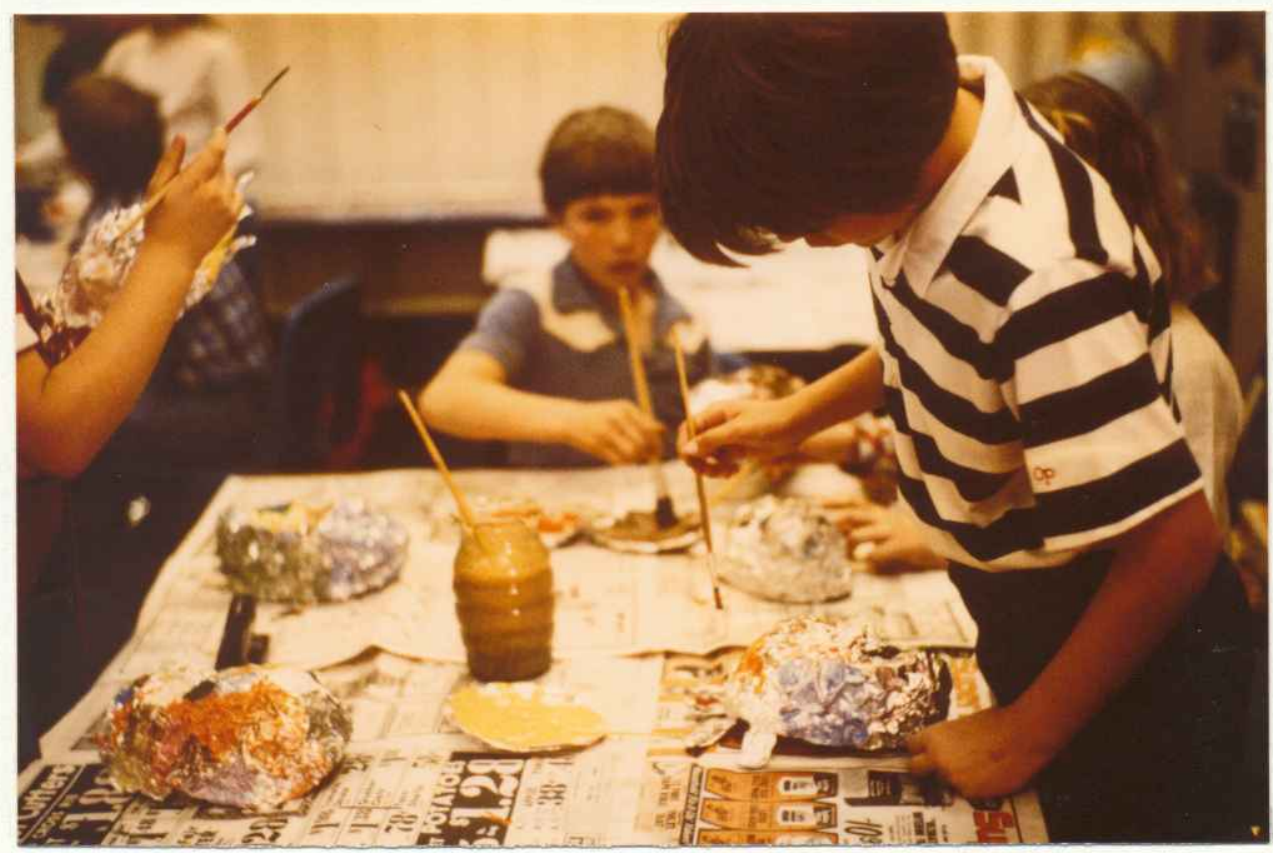

Figure 32 - Mask making 


\section{CHAPTER IV}

\section{CONCLUSIONS}

All the teachers with whom I cooperated on these and other projects agree with me that an integrative approach, though perhaps more demanding on the teacher, is more satisfying and exciting in the process as well as in the results. They also agree that art can be a tremendously versatile tool if one knows how to use it creatively in bringing out the best in children.

These scattered projects which I was able to conduct do not in themselves demonstrate the benefits of art instruction allied with academic curriculum. However, they indicate that there can be strong ties between the art experiences and the learning processes of other academic disciplines, very likely reaching beyond only momentary enthusiasm. This heightened ability to perform is caused by the involvement of all senses and emotions involved in the process. What then could be accomplished if art education were to be employed systematically and to fuller creative advantage for the growth of the student potentials?

My experiments suggest that a measurable and more persuasive study could be conducted if a researcher were to observe team of an art teacher and a class teacher, or perhaps a highly creative and artistically well educated classroom teacher alone, comparing two classes of the same grade and of approximately similar-achieving abilities. In one class, a 
well designed art-integrative approach would be applied, while the other class would be used as a control group, with traditional teaching continued. Such a study would have to last at least one year, although five years would be ideal for making the specific results indisputable.

Since I have stressed the benefits of the integrative qualities in my study, I must also warn that it would be a mistake to use art only in conjunction with other subjects. We would then miss the whole point, as has happened previously in the educational field. Art cannot be used as a crutch. It deserves consideration as a co-equal of other subjects if only because "it is just as hard to train the eyes and the hands as it is to teach the handling of words". 44

In the preparation of teachers for integrative teaching, the personality and personal skills of the individual teacher play a major role in connecting art with other subjects. The creative teacher, properly educated in art, may be more successful in approaches which require the ability to change plans on the spot if the learning situation calls for it. But this especially requires a familiarity with specific art processes, materials as well as theoretical knowledge.

Another possible route could be the cooperation of an art specialist with classroom teachers. However, this prospect looks dim in the present situation when even art teachers are losing positions due to budget difficulties.

In such light it seems ridiculous that the Oregon Department of Education requires teachers to give art instruction in the elementary grades without requiring practical know-how. It is presumptuous to

${ }^{44}$ The Open Eye in Learning, p. 57. 
believe that a booklet can be an adequate substitute for current knowledge and personal experience. This error of generality then is repeated by requiring our children to "understand concepts" and "demonstrate skills" without the necessary opportunity to genuinely acquire them.

I don't think there should be any doubt about teaching art to children - it has fulfilled the basic human need for expression since pre-historic times. It provides educators with a wealth of information about past and present cultures in visual form supplying alternatives to only the verbal forms. It can help to stimulate children's interest in learning because through art experiences children can gain a deeper, more personal understanding of concepts and a greater respect for knowledge in general. The question is how can art experience contribute to the fullest potential of intellectual and emotional growth of children?

Bringing creative approaches to the task of solving integration of art within existing curricular structures may prove to be a practical solution toward maintaining quality in times of financial exigency. Although teachers will need practical help to develop skills and knowledge for their new roles in the integrative teaching process, the budgetary pinch may not then prove to be an unsurmountable problem. 
American Association for the Advancement of Science. Science...A Process Approach II. Lexington, Mass., Ginn and Comp., 1974.

Barkan, Manuel. A Foundation for Art Education. New York, The Ronald Press Co., $\overline{1955 .}$

Bassett, Richard, Ed. The Open Eye in Learning. Cambridge, Mass., The MIT Press, 1969.

Brannan, Steve and Leitschuh, Carol, Ed. An Oregon Report: Art and the Handicapped. Portland, Portland State University, 1976.

Burton, William H. The Step Beyond: Creativity. Washington, D.C., National Educational Association of the United States, 1964.

Comenius, Jan Amos. Scholarum Reformator Pansophicus. translated to Czech by Jan Patockka, Praha, St dtn' Pedagogické nak ladatelstvi, 1956 .

Edwards, Betty. Drawing on the Right Side of the Brain. Los Angeles, J.P. Tarcher, Inc., 1979.

Jameson, Kenneth. Primary School Art. New York, Van Nostrand Reinhold Co. 1971.

Kinsbourne, Marce1. "Sad Hemisphere, Happy Hemisphere." Psychology Today. May 1981.

Landis, Mildred M. Meaningful Art Education. Illinois, Chas. A. Bennett Co., Inc. Publishers, 1951.

Lowenfeld, Viktor and Brittain, W. Lambert. Creative and Mental Growth. 5th ed., London, The Mcmillan Co., 1970.

National Art Education Association. Art Education in the Elementary School. Ed. Mary M. Packwood, Washington, D.C., 1967.

National Art Education Association. Arts Education and Back to Basics. Ed. Stephen H. Dobbs, Virginia, 1979.

National Art Education Association. Creativity and Art Education. Ed. W. Lambert Brittain, Washington, D.C., 1964

National Art Education Association. Research in Art Education. Ed. Jerome Hausman, 9th Yearbook, Washington, D.C., 1959. 
Oregon Department of Education, Oregon Alliance for Arts Education. Art Advocacy Conference. 3rd annual, Salem, March 27, 1981. (unpublished notes)

Read, Herbert. Education Through Art. 2nd edition, New York, Pantheon Books, A Division of Random House, n.d.

Torrance, Paul E. Guiding Creative Talent. Englewood Cliffs, N.J., Prentice-Hall, 1962.

Winslow, Leon Loyal. The Integrated School Art Program. New York, McGraw-Hi 11 Book Co., 1939. 